\title{
Determinants of Farmers' Level of Interaction with Agricultural Extension Agencies in Northwest Ethiopia
}

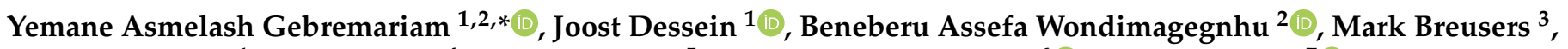 \\ Lutgart Lenaerts ${ }^{1}$, Enyew Adgo ${ }^{4}$, Zemen Ayalew ${ }^{5}$, Amare Sewenet Minale ${ }^{6}\left(\mathbb{D}\right.$ and Jan Nyssen ${ }^{7}$ (i) \\ 1 Department of Agricultural Economics, Ghent University, 9000 Ghent, Belgium; \\ Joost.Dessein@UGent.be (J.D.); lutgart.lenaerts@nmbu.no (L.L.) \\ 2 Department of Rural Development and Agricultural Extension, Bahir Dar University, \\ P.O. Box 5501 Bahir Dar, Ethiopia; benassefa1998@gmail.com \\ 3 Institute for Anthropological Research in Africa, KU Leuven, 3000 Leuven, Belgium; \\ mark.breusers@kuleuven.be \\ 4 Department of Natural Resource Management, Bahir Dar University, P.O. Box 5501 Bahir Dar, Ethiopia; \\ enyewadgo@gmail.com \\ 5 Department of Agricultural Economics, Bahir Dar University, P.O. Box 5501 Bahir Dar, Ethiopia; \\ zayalew@gmail.com \\ 6 Department of Geography and Environmental Studies, Bahir Dar University, P.O. Box 79 Bahir Dar, Ethiopia; \\ amare1974@gmail.com \\ 7 Department of Geography, Ghent University, 9000 Ghent, Belgium; Jan.Nyssen@UGent.be \\ * Correspondence: YemaneAsmelash.Gebremariam@UGent.be
}

check for

updates

Citation: Gebremariam, Y.A.;

Dessein, J.; Wondimagegnhu, B.A.;

Breusers, M.; Lenaerts, L.; Adgo, E.;

Ayalew, Z.; Minale, A.S.; Nyssen, J.

Determinants of Farmers' Level of

Interaction with Agricultural

Extension Agencies in Northwest

Ethiopia. Sustainability 2021, 13, 3447.

https://doi.org/10.3390/su13063447

Academic Editor: Andrea Pezzuolo

Received: 17 February 2021

Accepted: 17 March 2021

Published: 20 March 2021

Publisher's Note: MDPI stays neutral with regard to jurisdictional claims in published maps and institutional affiliations.

Copyright: (c) 2021 by the authors. Licensee MDPI, Basel, Switzerland. This article is an open access article distributed under the terms and conditions of the Creative Commons Attribution (CC BY) license (https:// creativecommons.org/licenses/by/ $4.0 /)$.

\begin{abstract}
This research identifies critical determinants for interactions between farmers and extension agencies. Cross-sectional farm household-level data from three hundred household heads were collected between September 2019 and March 2020 and triangulated with data from workshops with farmers and extension agents. The data were analyzed using Spearman's correlation coefficient, Kruskal-Wallis analysis of variance and the ordered probit model. Farmers' socio-economic characteristics significantly affect their degree of interaction with extension agencies. Recognition of the determinants of the level of farmers' interactions can inform policymakers about how to formulate and improve the effectiveness of extension programs, enhance information and knowledge dissemination and facilitate development in collaboration with local communities by focusing on a better interaction between farmers and extension agencies. The level of a farmer's interactions is based on a systematic decision-making process. Although personal and demographic characteristics are important, farmers' interaction levels require conducive institutional and household assets, groups/social capital and access to extension agents' contexts. These contexts will differ by household, country and region. Therefore, extension agencies should create and design contextually appropriate strategies for substantial interactions with farmers for the dissemination of farm information. This research is original and valuable in identifying the factors associated with the level of farmers' interactions with extension agencies in the Amhara region, Ethiopia. It also provides a new pathway for operationalizing farmer-oriented agricultural extension policies and strategies and to help agricultural policymakers formulate extension service programs.
\end{abstract}

Keywords: determinants; interaction; public extension; ordered probit model; Ethiopia

\section{Introduction}

Farmers require timely, adequate and appropriate information to help them increase production and their incomes and market their products effectively [1]. Extension services play a vital role in these aspects. These services provide a tool to lessen extreme poverty and reduce hunger in developing countries [2]. Agricultural extension is also expected to respond to emerging issues such as crop infestations. Extension services need to be demanddriven, relevant to farmers and responsive to their needs [3]. As farmers are one of the key 
stakeholders at the grassroots level, their participation in developing and disseminating technology contributes to the efficiency and effectiveness of any planned changes.

Farmers are exposed to many sources of farm-related information from public and private organizations. In many developing economies, their interactions with various stakeholders in extension services, which cover topics that include improving the sustainability of their farming systems, marketing strategies, environmental sustainability, pest diagnostics and risk management, have increased [4]. Farmers' access to information and knowledge is an essential component of sustainable agriculture and farmers need to be motivated to take responsibility for public agencies' extension programs.

Previous studies have shown that extension service providers create valuable information, knowledge and technology dissemination, usually adapted to the specific context of the country or region in which they work [5]. Barrett, et al. [6] argued that access to transparent sources of information and knowledge is an indicator of community empowerment and is essential to improving rural livelihoods. Amankwah, et al. [7] and Charles, et al. [8] also showed that interactions with extension agents and other actors in the agricultural sector increase smallholder farmers' access to information, knowledge and farming inputs, thus contributing to agricultural innovation. Access to information supports farmers in deciding whether or not to adopt agricultural technologies [9]. A study carried out in Namibia by Kumba [10] asserted that farmers access and utilize information more effectively if they have built interactions with the institutions and arrangements that impart the knowledge and information. This leads farmers to develop a sense of ownership in the endeavors of extension activities and programs. Interaction is essential to smoothen the development processes that explicitly deliver desired, technology-related outcomes for participants [11]. Previous research has also shown that interactions encourage implementing the latest technologies and best practices, thus improving farmers' productivity and incomes [12].

Farmers' level of interaction with extension services is inevitably affected by socioeconomic and demographic factors. Since these interactions take place at the grassroots level, they are inherently dependent on the specificities of this grassroots context. Determining these influences on the level of interaction at the grassroots level can provide an important contribution to formulating policies and strategies that can enhance the dissemination of information and knowledge and facilitate development in collaboration with local communities. Based on research in Vietnam, Hoang, et al. [13] noted that factors such as ethnicity, gender and power relations determine farmers' interactions with public extension services. Research from the Democratic Republic of Congo [14] and Malawi [15] reported a dearth of interaction between extension agencies and farmers with the former failing to deliver knowledge and technologies to farmers. Here, farmers' socio-economic characteristics were not considered, and extension agents were unable to develop and recommend appropriate technologies that were compatible with farmers' expectations and needs. For northwest Ethiopia, little is known about socio-economic factors determining farmers' interactions with public extension services [16-20].

The agricultural sector in Ethiopia contributes to the livelihood of most of the country's households. It remains the keystone of the Ethiopian economy both in terms of employment and income generation. The reduction in poverty in Ethiopia will not be possible without rapid agricultural development, ignited by an effective extension system [21]. However, as Belay [22] noted, the country suffers from insufficient agricultural technology, inadequate natural resource management, a minimal use of farm inputs and insufficient knowledge of agriculture. Such problems are exacerbated by a weak extension system, poor interactions between farmers and public extension agencies, land fragmentation, a weak financial market and poor rural infrastructure [23]. Despite the enormous investment in agricultural extension programs, the services have been widely criticized for their inadequate targeting, restricted scope and the immense administrative costs of information delivery [22,24-26]. This has led Ethiopia's government to devise and pursue agricultural extension policies and approaches aimed at alleviating these problems, minimizing dependence on rain-fed agriculture and ensuring food security. 
This paragraph explains the organization of the Ethiopian extension apparatus in order to sketch some specificities of the grassroots context of this study. At the district level, the local agricultural offices' main tasks are to promote crop and animal production, facilitate credit and marketing services and introduce modern agricultural technologies, thereby intensifying agricultural growth. They also support and supervise the frontline extension agents who work in promoting agricultural activities at the sub-district level. These extension agents play a central role in agriculture and rural development initiatives. After the launch of the first Growth and Transformation Plan (GTP-I) in 2010, the Ministry of Agriculture (MoA) adopted a Participatory Extension System (PES) [27]. This system organizes local farmers into "development groups", "1 to 5 farmers' groups" and other networks. Under PES, each sub-district is subdivided into three villages (ketena), working though development groups, consisting of 20 to 30 farmers, each headed by a model farmer [28]. Each village has 6 to 10 development groups. Extension agents (EAs) mentor and assist the development group leaders and train model farmers who, in turn, do the same to the members of their respective farmers' group. The development group leaders regularly evaluate the farmers' performance, based on the quality of the work conducted and the farm tools used. The sub-district cabinet assigns one EA to each village on a rotational basis, according to their specialization. The arrangement is intended to enhance learning among farmers and encourage them to adopt best practices [24]. Extension agents and farmers are also supposed to participate in Farmers' Training Centers (FTCs), where technologies are demonstrated for them to evaluate and where they can plan the coming year's campaign. Despite these efforts to make the extension system efficient and effective, the system has not produced the desired outcomes [28].

Non-governmental actors also provide extension services. Cooperatives are expected to play a role in mobilizing farmers and to provide different extension services, such as access to agricultural inputs, such as fertilizer and improved seed [29]. Farmers have also organized themselves into water users' associations (WUAs) to address irrigation and other water-related problems [30], since irrigation needs proactive and organized community participation [31].

Interactions between these extension agencies and farmers is critical, yet much of the literature is one-sided, solely focusing on the factors that affect farmers' participation in extension activities while paying little attention to the socio-economic factors that influence their level of interaction with extension agencies. Some research has covered watershed programs [16], entry and intensity in informal rental land markets [17], soil and water conservation intervention [18], the supply of off-farm labor [19] and the use of information communication technologies [20]. This study aims to fill the gaps in this research by identifying the critical socio-economic determinants of the interactions between farmers and extension agencies. Insights in these context-related specificities will lead to improved partnership, collaboration and linkages in such interactions, thereby improving the extension system at large. This study will also inform policymakers on ways of improving the effectiveness of extension programs by focusing on how to improve interactions between farmers and extension agencies. To this end, the key research questions of this paper are as follows: What are the determinants of the level of farmers' interactions with extension agencies? How do these determinants explain the level of farmers' interaction with the extension agencies?

The research was conducted in two districts near Lake Tana, northwest Ethiopia. North Mecha is recognized for its irrigation potential and is home to the international vegetable company Koga Veg (a Belgian-based enterprise that exports fresh fruit and vegetables). Fogera district is well known for its rain-fed rice and irrigated vegetable production. The extension services in the two districts are provided by a range of different public extension agencies located in the area. 
The rest of this paper is organized as follows. Section 2 explains the sampling techniques, sample size, data sources and types and analysis. Section 3 first describes and then discusses the descriptive statistics, tests and results of the econometric model. The final section provides some conclusions and recommendations.

\section{Materials and Methods}

\subsection{Site Information}

The study was conducted in two districts of the Amhara region, Fogera and North Mecha (Figure 1). These districts have been subject to extension activities implemented by the government, supported by various non-governmental organizations (NGOs) who have conducted and supported these extension endeavors. The detailed area description is found in Table 1.
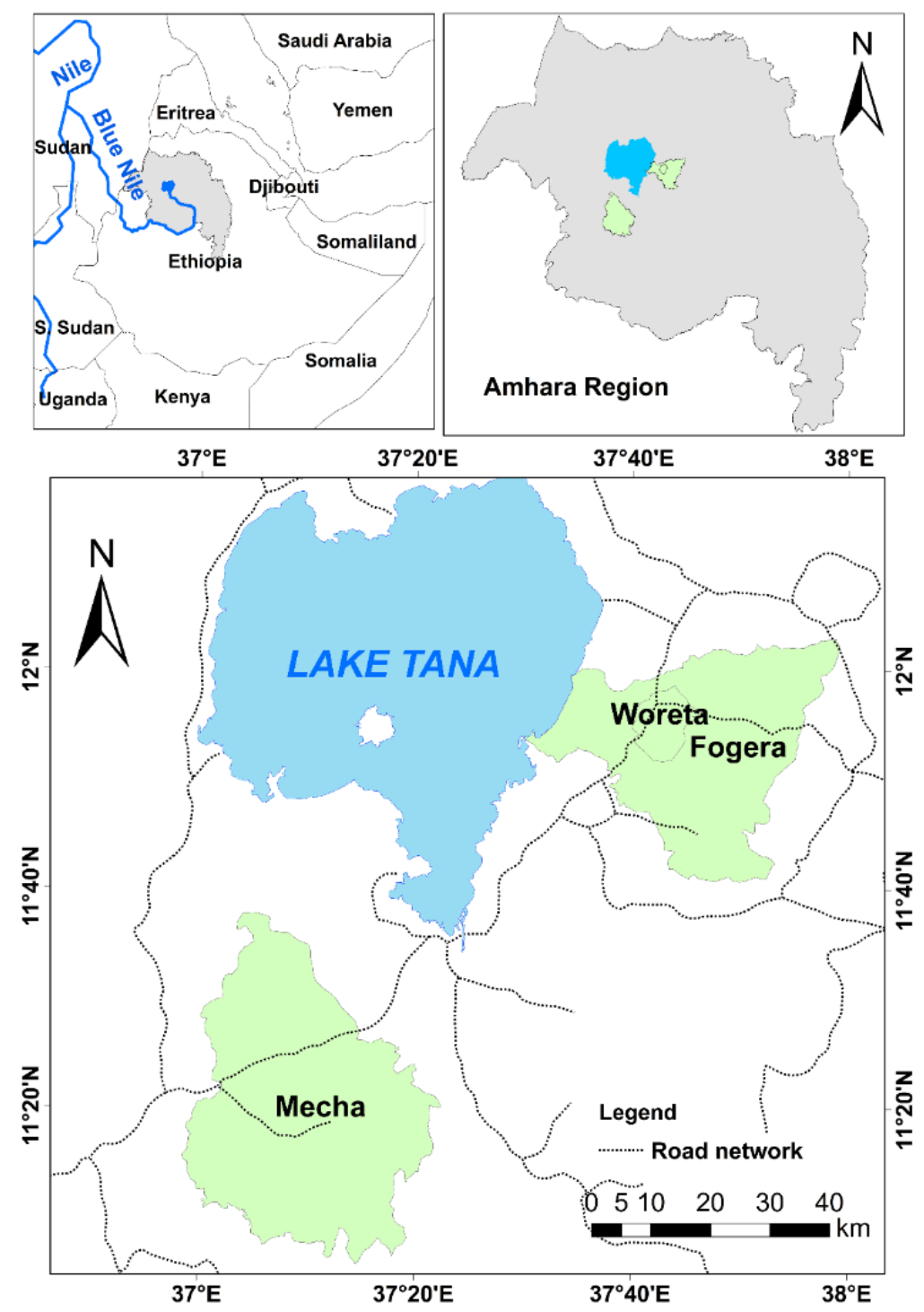

Figure 1. Map of the study area. 
Table 1. Description of the study area.

\begin{tabular}{|c|c|c|}
\hline \multirow{2}{*}{ Parameters } & \multicolumn{2}{|c|}{ Districts } \\
\hline & Fogera & North Mecha \\
\hline Altitude (m a.s.l) & $1774-2410$ & $1800-2500$ \\
\hline Temperature in ${ }^{\circ} \mathrm{C}$ : range (mean) & $12-28(20)$ & 6-31 (18) \\
\hline Annual rainfall in mm: range (mean) & $1103-2400(1216)$ & $1500-2200(1700)$ \\
\hline Total area (ha) & 117,414 & 159,027 \\
\hline $\begin{array}{l}\text { Cultivated crops in descending } \\
\text { order of dominance }\end{array}$ & $\begin{array}{l}\text { Teff, finger millet, maize, rice and noug } \\
\text { (Guizatia abyssinica) }\end{array}$ & $\begin{array}{l}\text { Maize, finger millet, teff, barley, pulses } \\
\text { and oil crops }\end{array}$ \\
\hline Dominant livestock & Cattle, sheep, goats & Cattle, sheep, goats \\
\hline Cultivated land (ha) & 51,472 & 72,178 \\
\hline Irrigated land (ha) & 13,800 & 7200 \\
\hline Forest and bushland (ha) & 2190 & 6339 \\
\hline
\end{tabular}

\subsection{Sampling Technique and Sample Size}

A multi-stage sampling technique that involved three stages of random sampling, based on the structure of natural clusters in the population, was used to obtain a representative sample for the analysis [34]. In the first stage, the two districts were purposively selected, based on the long-term provision of intensive public agricultural extension services, various agro-ecologies and their recognition as "development corridors" (i.e., with a large potential for agriculture and agro-processing) by the government. Given this context, it was assumed that farmers were aware of extension activities and could answer the research questions. In the second stage, eight villages were selected purposely from each selected district. Thirdly, systematic random sampling was employed to select respondents from a list of farmers residing in each sub-district, proportionate to the districts' size, resulting in a sample of 300 households (Table 2).

Table 2. Distribution of sample size.

\begin{tabular}{|c|c|c|c|c|c|}
\hline \multirow{2}{*}{$\begin{array}{l}\text { Name of the } \\
\text { Districts }\end{array}$} & \multirow[t]{2}{*}{ Village Name } & \multirow[t]{2}{*}{ Total HHs (N) } & \multirow{2}{*}{$\begin{array}{l}\text { Sample Size } \\
\text { (n) }\end{array}$} & \multicolumn{2}{|c|}{$\begin{array}{c}\text { Number of Farmers and Extension Agents in } \\
\text { Focus Group Discussions (FGDs) }\end{array}$} \\
\hline & & & & Farmers & Extension Agents \\
\hline \multirow{9}{*}{ Fogera } & Bebekes & 1765 & 22 & \multirow{9}{*}{16} & \multirow{9}{*}{10} \\
\hline & Kuhar Michael & 1337 & 16 & & \\
\hline & Woretazureya & 1979 & 24 & & \\
\hline & TihuanZakena & 1445 & 18 & & \\
\hline & Meneguzer & 1665 & 20 & & \\
\hline & Kuhar Abo & 784 & 10 & & \\
\hline & KidestHana & 2175 & 26 & & \\
\hline & Abunakokit & 1171 & 14 & & \\
\hline & Total & 12,321 & 150 & & \\
\hline \multirow{9}{*}{ North Mecha } & Ambo Mesk & 1386 & 20 & & \multirow{9}{*}{13} \\
\hline & Kudmi & 1886 & 27 & & \\
\hline & Anguti & 983 & 14 & & \\
\hline & Amarit & 606 & 9 & & \\
\hline & HuletTeleta & 1196 & 17 & \multirow{5}{*}{13} & \\
\hline & Bachima & 1830 & 26 & & \\
\hline & Brakat & 1284 & 18 & & \\
\hline & Kurt Bahir & 1320 & 19 & & \\
\hline & Total & 10,491 & 150 & & \\
\hline \multicolumn{2}{|c|}{ Grand total } & 22,812 & 300 & 29 & 23 \\
\hline
\end{tabular}




\subsection{Data Types and Sources}

This study followed a cross-sectional research design. The receivers of agricultural extension services in the districts were the focus of the study. A structured questionnaire was developed based on the study's objectives, literature review and the researchers' long-term experience in the area.

These quantitative results were complemented with qualitative data collected through focus group discussions ( 29 farmers and 23 extension agents from Fogera and North Mecha districts), allowing for a triangulation of the results of the survey with the reflections and observations of farmers, extension experts and district-level office heads. The focus group discussions helped the researchers get a clear idea and new insights concerning the determinant variables and how these can be related to the literature.

\subsection{Data Analysis}

Cross-sectional farm household-level data were collected between September 2019 and March 2020. The data were coded and filed in STATA software. The household questionnaire was administered to a group of 300 systematically selected household heads. Descriptive statistics were used to capture the socio-economic profile of respondents. Spearman's correlation coefficient and Kruskal-Wallis analysis of variance tests were used to determine statistically significant differences between two or more groups of independent variables. An ordered probit model allowed us to identify the determinant variables that influence farmers' levels of interaction with extension services, as discussed below.

\subsubsection{Specification of the Econometric Model}

Ordered probit and logit models are used when the dependent variable " $y$ " has the discrete ordered nature of the response. In an ordered probit model, the values of the response dependent variable are not arbitrary [35]. However, in the case of multinomial probit or logit models, the dependent variable is not in a certain order and therefore the categories of the values of the dependent variable have no meaning [36]. In this research, the ordered dependent variable is "level of interaction of farmers", which is categorized as "very weak", "weak", "strong" and "very strong", and valued as 1, 2, 3 and 4, respectively. Therefore, the effects of different determinant factors are estimated on the probability of each level of interaction. Although ordered probit and logit models yield similar inferences, they assume standard normal and logistic distributions of the error terms, respectively. An ordered probit model was used in this research as it is a commonly used tool in other related research such as [37-42].

Following Borooah [43], the interaction of individuals with extension services is affected by interdependent variables, as shown in Equation (1):

$$
y^{*}{ }_{i}=x_{i} \beta+\varepsilon_{i}
$$

where $y^{*}{ }_{i}=$ interactions with public extension agencies, with four levels of increasing interaction, coded as $1=$ very weak, $2=$ weak, $3=$ strong, and $4=$ very strong; $x_{i}=$ vector of observed random explanatory variables assessing the attributes of farmers' interaction; and $\varepsilon_{i}=$ a random error term to mean 0 and a variance, 1 . The observed $y$ is related to $y^{*}$ as specified in Equation (2):

$$
y_{i}\left\{\begin{array}{c}
1 \rightarrow \text { very weak }=-\infty \leq y_{i<}^{*} \tau_{1} \\
2 \rightarrow \text { weakif } \tau_{1} \leq y_{1}^{*}<\tau_{1} \\
3 \rightarrow \text { strongif } \tau_{2} \leq y_{i}^{*}<\tau_{3} \\
4 \rightarrow \text { very strongif } \tau_{3} \leq y_{i}^{*}<\tau_{4}
\end{array}\right.
$$


It follows that the equations for the probabilities with four observed outcomes for the ordered probit model are

$$
\left\{\begin{array}{c}
P_{\tau} y_{i}=1 / x_{i}=\varnothing\left(\tau_{2}-\alpha-\beta x_{i}\right) \\
P_{\tau}\left(y_{i}=2 / x_{i}\right)=\varnothing\left(\tau_{2}-\alpha-\beta x_{i}\right)-\varnothing\left(\tau_{1}-\alpha-\beta x_{i}\right) \\
P_{\tau}\left(y_{i}=3 / x_{i}\right)=\varnothing\left(\tau_{3}-\alpha-\beta x_{i}\right)-\varnothing\left(\tau_{2}-\alpha-\beta x_{i}\right) \\
P_{\tau}\left(y_{i}=4 / x_{i}\right)=\varnothing\left(\tau_{4}-\alpha-\beta x_{i}\right)-\varnothing\left(\tau_{3}-\alpha-\beta x_{i}\right)
\end{array}\right.
$$

The parameters of the model specified in Equation (3) are estimated using the maximum likelihood method. However, there is a lack of clarity in interpreting the model's coefficient [44]. For example, there are four categories of farmers' interaction with extension agents. At the same time, the model has only one unknown threshold parameter. This necessitates the partial change in the marginal effect, which can reveal the individual effects of independent variables on the probability of the four different levels of interaction. A partial change in the predicted probability of the outcome $\mathrm{m}$, for a continuous variable, in the interval $\tau_{m-1}$ to $\tau_{m}$ for a change in the explanatory variable $x_{k}$ at the mean value is specified as in Equation (4):

$$
\frac{\delta p_{\tau}(y=m / \bar{x})}{\delta x_{k}}=\beta_{k}\left[f\left(\tau_{m-1}-\bar{x} \beta\right)-f\left(\tau_{m}-\bar{x} \beta\right)\right]
$$

The change in the predicted probability that $y=m$ given $x$, stating a particular value for $x_{k}$ from the initial value $x_{s}$ to the end value $x_{\epsilon}$ (e.g., a change from $x=0$ to $x=1$ ), is given by Equation (5):

$$
\frac{\delta p_{\tau}(y=m \mid \bar{x})}{\delta x_{k}}=p_{\tau}\left(y=m \mid x, x_{k=X_{E}}\right)-p_{\tau}\left(y-m \mid x, x_{k=} x_{s}\right)
$$

where $p_{\tau}\left(y=m \mid x, x_{k}\right)$ states the probability that $y=m$ given $x$, given a particular value for $x_{k}$. Thus, when $x_{k}$ changes from $x_{s}$ to $x_{E}$, the predicted probability of the outcome $\mathrm{m}$ changes by $\Delta p_{\tau}(y=m \mid x) / \Delta x_{k}$, keeping all other variables at $x$.

\subsubsection{Description of Variables and Hypotheses}

In this study, a farmer's level of interaction was considered to be the dependent variable. Farmers were asked to rate their level of interaction with formal actors in the extension system as very weak (meet once per cropping season), weak (meet once per month), strong (meet every two weeks) and very strong (meet weekly). The independent variables concerned the socio-economic attributes of farmers, based on the assumption that farmers' interactions are influenced by a number of variables (Table A1), which are explained in the following paragraphs.

The sex of a household head may have a positive or negative effect on interactions. According to Mudege, et al. [45], men have more freedom and influence in household decision making than women, including opportunities for interaction with different extension agencies to learn about new practices and technologies and to participate in different events, such as meetings, demonstrations and training sessions. Due to the negative stereotypical views about women, their husbands and extension agents inhibit their access to training and knowledge. However, some studies [16,46,47] revealed that women are better networked in social groups, such as "program groups", and are actively involved in household and smallholding decision making.

A farmer's age is an important determinant of the level of interactions and is expressed as a continuous variable in this model. Since interaction in extension is mainly for the purposes of seeking information and knowledge, we surmise that young farmers are more likely to participate due to their higher education, enthusiasm and desire to learn and to access a range of different information sources. This is particularly the case in soil and water conservation works that require considerably more investment in technologies $[48,49]$. 
A household head's farm experience is defined as the number of years spent in farming by the household head [50]. The experience will enable farmers to have better knowledge, which may be the basis for interaction [31]. Hence, farming experience was hypothesized to affect farmers' interaction positively. Participation in agricultural extension programs and activities requires that a household has a sufficient agricultural labor force [51]. The family is the major supplier of the labor needed for undertaking the farming operations [52]. Accordingly, we hypothesize that the agricultural active labor force in the household will be positively correlated with a farmer's decision to interact with public extension agencies while delegating their responsibility to another family member.

Dependents are defined as persons living in the household who make little or no contribution to agricultural activities in terms of labor but consume household resources (i.e., those of less than 15 years or older than 64) [53,54]. A farm household with more dependents is assumed to be less likely to interact with extension agencies as they cannot delegate labor while interacting with extension agents. Therefore, a higher number of dependents is expected to negatively influence the interaction with extension agencies.

The level of education of the household head, measured as a categorical variable, is expected to positively influence farmers' interaction with different extension agencies. Several studies have revealed the positive effect of education levels on farmers' participation in extension programs and technology adoption [51,55]. Many farmers are also involved in non-farm activities in order to support their income and livelihood. This is an indication that income from the farm enterprise alone is inadequate [56]. Therefore, it is hypothesized that involvement in non-farm activities is negatively correlated with the farmers' interaction with extension agencies.

Farmers who have access to agricultural credit are under pressure to pay back, especially when confronted with challenges such as a failed harvest. Consequently, farmers with agricultural credits are more likely to interact with various agencies, in order to obtain adequate information and know-how to improve their production, ensure their income and pay back their debts in time. Farmers who join cooperatives and informal organizations such as Iddirs (An Iddir is an association made up by a group of people united by ties of family and/or friendship, living in the same district, etc., that has an objective of providing mutual aid and financial assistance when needed [57]) and Mahibers (A Mahiber is a self-help religious organization established by the common interest of members [58] may have more interest in communicating with public extension agencies [53]. Household membership of cooperatives and informal organizations is hypothesized to positively influence interaction with extension agencies.

The interaction of household heads with extension agencies is also affected by the time required for the interaction [51]. The distance (measured in minutes) from a farmer's house to the nearest extension agent's office will influence the probability of interacting, and greater distances are hypothesized to influence interactions negatively.

Farmers who attend more annual training and field days are likely to have more opportunities to interact with different public extension agencies [59]. Therefore, farmers' participation in extension training sessions and field days is likely to have a positive effect on their interactions and increase the probability of these occurring.

Oxen ownership is an essential component of developing countries' agricultural economies [58,60,61]. It is also closely linked to the social and cultural lives of farmers [62]. Adopting the technologies promoted by extension agencies requires farmers to have means and to be relatively wealthy. As wealth is expressed in oxen ownership in the research area, oxen ownership is expected to be positively associated with interactions with extension agencies.

Agricultural land is a fundamental base of rural livelihoods [63]. Household landholding size (be it irrigated or leased) has been reported to be strongly associated with farmers' interaction with extension agencies [64]. In this study, we hypothesize that farm size (size of leased and irrigated land) will be positively associated with respondents' interactions with extension services. 
Farmers can obtain information from different sources [65] including the mass media, particularly the radio [25]. We expect such exposure to positively influence farmers' interactions with extension services.

Farmers use mobile phones for accessing market information, arranging meetings with extension services, reporting an emergency, organizing meetings and communicating with extension agents [66]. Ownership of a mobile phone is assumed to help farmers interact with extension personnel and is hypothesized to positively influence farmers' interactions.

Finally, the rural households in the study areas were classified into three wealth ranks (poor, medium and better off) by the extension agents, based on their overall physical assets. We use the term wealth status and hypothesize that the better-off farmers will have better interactions with extension agencies.

\section{Results and Discussion}

\subsection{Descriptive Statistics}

3.1.1. Statistical Summary for the Continuous Variables of the Study

Table 3 presents the summary statistics of the variables. The mean age of a farm household head is around 43 years. The mean numbers of dependents and economically active family members are 2.3 and 3.3, respectively. On average, farmers participate in 3.5 days of agricultural training and 1.1 field days per year. While the extension agencies organize formal training and field day sessions for farmers, farmers in the focus group discussions (FGDs) complained that priority for participating in these events was given to "model farmers" as it was assumed that they would disseminate information and knowledge through peer-to-peer learning. A similar observation was recently made by [67].

Table 3. Characteristics of respondents.

\begin{tabular}{cc}
\hline Continuous Variables & Mean (Std. Dev) \\
\hline Age of farmer & $42.9( \pm 10.4)$ \\
\hline Farming experience of the head & $24.1( \pm 10.4)$ \\
\hline Economically active family members & $3.3( \pm 1.6)$ \\
\hline Dependent family members & $2.3( \pm 1.4)$ \\
\hline $\begin{array}{c}\text { Average journey time (on foot) for farmers to } \\
\text { their nearest extension agent }\end{array}$ & $25.6( \pm 18.9)$ \\
\hline Days of agricultural training per year & $3.5( \pm 3.9)$ \\
\hline Field days per year & $1.1( \pm 1.3)$ \\
\hline Average number of oxen per household & $2.2( \pm 0.9)$ \\
\hline Self-owned irrigated land & $0.3( \pm 0.4)$ \\
\hline Cultivated leased land & $0.2( \pm 0.3)$ \\
\hline Ownership of radio & $0.4( \pm 0.5)$ \\
\hline Ownership of mobile phone & $1.3( \pm 1.0)$ \\
\hline
\end{tabular}

Note: Number of observation is 300.

The average journey time (on foot) for farmers to their nearest extension agent is a little over $25.6 \mathrm{~min}$. This relative proximity does not suggest an impediment to interacting with extension agencies. Oxen, commonly used in Ethiopia for plowing, are generally considered as an asset that can be used either in the production process or sold in times of hardship [68]. The average number of oxen per household among our respondents was 2.2. This implies that farmers in the study areas have good opportunities to cultivate their land and have some "back-up savings".

On average, household heads cultivate 0.2 hectares of leased land and 0.3 hectares of self-owned irrigated land. This indicates that farmers who do not own (enough) land 
can rent land in kind or for cash. However, the focus groups revealed that leased lands are expensive and usually not irrigated and are thus far less productive than owned (and irrigated) land.

Mobile phones are used as a medium for sharing and accessing information. With an average of 1.3 numbers of cell phones in the households in our sample, a large proportion of farmers can easily access agricultural information from extension agencies.

\subsubsection{Statistical Summary for Discrete Variables of the Study}

The statistical analysis of the discrete variables of the study is given in Tables 4 and 5 .

Of all households, $95 \%$ are male-headed, and $5 \%$ are female-headed (Female-headed households are characterized as single women, married women whose husbands are absent or widows). In the FGDs, farmers confirmed that male-headed households have more access to extension services and better representation in local and governmental organizations.

According to Table 4, 4\% attended secondary school, while 38\% can read and write. These household heads in the study area have a relatively better educational position that helps their interactions with public extension agencies.

Table 4. Summary for categorical variables.

\begin{tabular}{|c|c|c|c|}
\hline $\begin{array}{c}\text { Dummy and } \\
\text { Categorical Variables }\end{array}$ & Responses & Frequency & Percentage \\
\hline \multirow{2}{*}{ Sex } & Male & 286 & 95 \\
\hline & Female & 14 & 5 \\
\hline \multirow{4}{*}{ Literacy } & Illiterate & 98 & 33 \\
\hline & $\begin{array}{c}\text { Literate } \\
\text { (just read and write) }\end{array}$ & 113 & 38 \\
\hline & Primary school & 77 & 26 \\
\hline & Secondary school & 11 & 4 \\
\hline \multirow{2}{*}{$\begin{array}{l}\text { Engagement in non-farm } \\
\text { activities }\end{array}$} & No & 243 & 81 \\
\hline & Yes & 57 & 19 \\
\hline \multirow{2}{*}{ Access to credit } & No & 184 & 61 \\
\hline & Yes & 116 & 39 \\
\hline \multirow{2}{*}{ Membership to an Iddir } & No & 39 & 13 \\
\hline & Yes & 261 & 87 \\
\hline \multirow{2}{*}{ Membership to a Mahiber } & No & 80 & 27 \\
\hline & Yes & 220 & 73 \\
\hline \multirow{2}{*}{ Membership to a cooperative } & No & 77 & 26 \\
\hline & Yes & 223 & 74 \\
\hline \multirow{2}{*}{ Access to irrigation } & No & 88 & 29 \\
\hline & Yes & 212 & 71 \\
\hline \multirow{3}{*}{ Income status of household } & Poor households & 38 & 13 \\
\hline & $\begin{array}{l}\text { Middle-income } \\
\text { households }\end{array}$ & 200 & 67 \\
\hline & Better-off households & 62 & 21 \\
\hline
\end{tabular}


Table 5. Distribution of farmers across information sources.

\begin{tabular}{|c|c|c|c|}
\hline Information Sources & Level & Frequency & Percent \\
\hline \multirow{4}{*}{ Extension agents } & Very weak & 13 & 4 \\
\hline & Weak & 26 & 9 \\
\hline & Strong & 76 & 25 \\
\hline & Very strong & 185 & 62 \\
\hline \multirow{4}{*}{$\begin{array}{c}\text { The district office of } \\
\text { agriculture }\end{array}$} & Very weak & 214 & 71 \\
\hline & Weak & 65 & 22 \\
\hline & Strong & 10 & 3 \\
\hline & Very strong & 3 & 1 \\
\hline \multirow{4}{*}{1 to 5 farmers' groups } & Very weak & 77 & 26 \\
\hline & Weak & 106 & 35 \\
\hline & Strong & 79 & 26 \\
\hline & Very strong & 38 & 13 \\
\hline \multirow{4}{*}{ Development groups } & Very weak & 91 & 30 \\
\hline & Weak & 119 & 40 \\
\hline & Strong & 64 & 21 \\
\hline & Very strong & 26 & 9 \\
\hline \multirow{4}{*}{$\begin{array}{l}\text { Multi-purpose } \\
\text { cooperatives }\end{array}$} & Very weak & 116 & 39 \\
\hline & Weak & 98 & 33 \\
\hline & Strong & 5 & 2 \\
\hline & Very strong & 4 & 1 \\
\hline \multirow{4}{*}{$\begin{array}{l}\text { Water users' } \\
\text { associations }\end{array}$} & Very weak & 35 & 12 \\
\hline & Weak & 51 & 17 \\
\hline & Strong & 26 & 9 \\
\hline & Very strong & 24 & 8 \\
\hline
\end{tabular}

The majority of the households (67\%) are classified as middle-income groups. Almost one fifth, $19 \%$, of the farmers are engaged in non-farm activities, indicating that the vast majority of farmers are not involved in additional income-generating activities to diversify their livelihoods. This might be because farmers prefer not to be involved in such activities or have limited opportunities to do so.

Just over a third (39\%) of the respondents have access to credit. According to the focus group participants, the micro-finance provider, The Amhara Credit and Saving Institution (ACSI), asks for a too high interest rate and also imposes a group collateral system arrangement that obliges farmers to organize in groups to share a mutual loan repayment guarantee [69]. Recent research on ACSI recommended that it "devise operations and marketing strategies that focus on the dominant service quality dimensions to enhance customer satisfaction and, in turn, foster positive customer loyalty" [70].

Social relations and social networks, such as Iddirs and Mahibers, are essential for the creation and sharing of knowledge among farmers and offer a more pluralistic approach to extension as well as smoothing farmers' access to extension agencies. Similar patterns can be found in many other countries in the Global South [71]. The survey showed that $87 \%$ of the respondents are members of an Iddir and $73 \%$ are affiliated with a Mahiber.

Many rural areas in Ethiopia are home to multi-purpose cooperatives that play a crucial role in improving their communities' socio-economic situation [72]. This study found 
that almost three quarters $(74 \%)$ of farmers are members of multi-purpose cooperatives, which also enhances their opportunities to interact with extension service providers.

Several rivers (including the Gumara, Ribb and Koga) flow through the study areas, so many North Mecha and Fogera farmers are engaged in small-scale irrigation farming [73]. More than two thirds (71\%) of respondents reported having access to irrigation, which tended to enhance interactions with various extension agencies. These farmers obtain training on cultivation methods, knowledge about local irrigation methods, help in preparing and implementing an irrigation schedule for supplying water to the fields and assistance in repairing and maintaining the irrigation canals.

Table 5 portrays the different sources of information that farmers use. Farmers were asked about their most important information source from the public extension agencies; $62 \%$ of the households met extension agents weekly which shows a very strong level of interaction. Public extension agencies were, by far, the most frequently used source of information. See Table 5 below for the rest of the analysis on information sources and the level of farmers' use.

\subsubsection{Analysis of Spearman Rank Correlation and Kruskal-Wallis Variance}

A Spearman rank correlation was used as a measure of a monotonic association, and a Kruskal-Wallis analysis of variance test was used to determine if there are statistically significant differences between two or more groups of independent variables such as educational status (illiterate, literate, primary school and secondary school) and wealth status (poor, middle-income and better off). Details of these analyses are in Appendix A (Tables A2 and A3).

\subsection{Determinants of Farmers' Interactions with Extension Agencies: Econometric Results}

This section presents the econometric estimation results of the determinants of farmers' interaction levels with different formal actors in the extension system. The parameter estimates of the ordered probit model are presented in Table A4. The variables found to be statistically significant in determining the level of farmers' interaction include the age of the household head, the farming experience of the head, the numbers of active family members and dependents, membership to Iddirs and Mahibers, physical distance to the extension agent's office, annual participation in agricultural training and field days, access to irrigation, oxen ownership, the amount of leased and irrigated land cultivated by the household, ownership of a radio and the wealth status of the household.

\subsubsection{Personal and Demographic Characteristics}

Sex of the household head: Various studies have shown that farmers' interaction with extension agencies is influenced by the sex of the household head [4,74]. In our study, male-headed households are also more likely to interact with cooperatives. Male-headed households are $35 \%$ more likely to have interactions with local cooperatives. The results from the FGDs suggest that this could be because there is an active male-headed household interaction due to their household decision-making power. Males are also more strongly represented in decision-making and leadership positions in the cooperative structure than females.

Moreover, female-headed households face obstacles in accessing resources, particularly land, and ownership of land is often a precondition for being able to join a cooperative. This aligns with the results obtained by [75], who investigated factors influencing women's participation in agricultural cooperatives in Ethiopia and concluded that their lower socioeconomic status plays a key role.

Age of the household head: Older farmers are less likely to interact with cooperatives. Interaction with cooperatives decreases by $4 \%$ for each additional year of a household head's age. This might be because farmers reduce their participation in cooperatives as they get older and become less willing to take on responsibilities and obligations. This result is 
consistent with other findings [76,77], both of which investigated the negative association between age and farmers' willingness to engage in natural resource management programs.

Number of active family members: Having more active family members decreases the level of farmers' interaction with water users' associations by about $5 \%$. This result is unexpected as active family members can alleviate any labor shortage and a large family size implies a high availability of labor [78] that exists within a household. The water users' associations are supposed to support farmers in any endeavors related to irrigation facilities, with the farmers expected to clean the irrigation canals themselves. However, as we understood through our FGDs, the associations often do not meet the farmers' needs, making membership and active participation less attractive. Similar findings have been found in earlier studies $[79,80]$ in which farmers without sufficient support for work from their active family members have to hire labor at peak times (e.g., for planting teff). This has a negative impact on farmers' incomes because of higher costs for land preparations, planting, weeding or harvesting activities [81].

Number of dependents in the family: This variable has a positive relationship with farmers' interactions with cooperatives and was statistically significant at $6 \%$. It may be that households with a large number of dependents wish to interact with cooperatives as the cooperatives are the sole providers of consumable goods (sugar, soap and edible oil) at a fair price for members and the allocation of these items is based on household size. Our results contradict some earlier results that farmers with a large number of dependents interact less with cooperatives. The contrary results can be explained by households with fewer children having a larger impact on the cooperative membership of smallholder wellbeing [82]. This is consistent with the study conducted by Priscilla, et al. [83] on dairy farmers' participation in dairy cooperative societies in Manipur (India), which showed that farmers with a larger dependent family size were more likely to participate in a dairy cooperative society, as they could leave their dependents to manage the dairy cattle when they attended cooperative activities and meetings.

The educational level of the household head: The result shows that household heads who can read and write, but did not complete their primary or secondary education, were positively and significantly more likely (9\%) to interact with a 1 to 5 farmers' group than other farmers. A probable explanation is that these farmers are recruited to be leaders of the 1 to 5 farmers' groups and play a role in interpreting and directing the public extension issues that cascade from various actors, and that those who complete their primary and secondary education consider themselves (or are considered) overqualified for these tasks. Moreover, farmers of this group are often promoted to become chairs of the 1 to 5 farmers groups and obtain some incentives for regularly sending written reports to government officials. This implies that accessibility of agricultural information for farmers who can read and write increased through their role in the 1 to 5 farmers' groups, which allows them to obtain a better position in the society. These results are consistent with Pratiwi and Suzuki [84], who found a significant positive relation between farmers' education level and their engagement in social networks aimed at knowledge acquisition in rural Indonesia.

Farm experience of the household head: The result shows that each additional year of farming experience results in a $1 \%$ reduction in the probability of interacting with the district office of agriculture but increases the probability of interacting with cooperatives by $1.82 \%$. This implies that people with more experience are more likely to be members of a cooperative. The FGD results suggested that this could be because the more experienced household heads are more likely to dedicate their time to interactions with related agricultural cooperatives for different agricultural and non-agricultural services, especially as agricultural cooperatives are the major end of line distributors of fertilizers and seed. The finding confirms a recent study elsewhere in Ethiopia by $[85,86]$.

\subsubsection{Institutional Characteristics}

Access to irrigation: Access to irrigation had a positive and significant effect $(1 \%)$ on the level of farmers' interactions with 1 to 5 farmers' groups and development groups. 
Farmers with access to irrigation were $14 \%$ more likely to interact with 1 to 5 farmers' groups and $14.78 \%$ more likely to interact with development groups. This could be because irrigation farming requires facilities, technologies, knowledge and skills, leading these farmers to interact with these user groups at the local level. As a consequence, irrigation in the study areas leads to an increase in yield and hence increases in income, consumption and food security. There are also other stakeholders in the area, such as NGOs and private sector actors, which are committed to supporting irrigation users to address low levels of skills that have hitherto constrained farmers' productivity in irrigation schemes. It has been shown elsewhere that farmers who have access to irrigation are more likely to obtain information, complementary inputs and incentives from government agencies. The results are consistent with the finding of [87] on the impact of small-scale irrigation on household food security in the case of the Filtino and Godino irrigation schemes in Ethiopia.

\subsubsection{Household Assets}

Irrigated land size cultivated by the household: Public extension interactions with local people in the community enhances their knowledge of various irrigation issues [88] and helps improve their use of irrigation water by providing them with the requisite knowledge, skills, commitment and understanding. However, farmers with more than one hectare of irrigated land were less likely to interact with extension agents, the district office of agriculture, 1 to 5 farmers' groups, farmers' development groups and water user associations, by factors of $2 \%, 17 \%, 11 \%, 18 \%$ and $20 \%$, respectively. This negative correlation results from the distrust between farmers and the government: farmers assume that the government is eager to hand over irrigated land to private investors and this leads them to resist disclosing the amount of irrigated land they possess. Compensation for any land taken by the government from the farmers is not based on the amount of irrigated land. Similar findings were reported by [89] on irrigation governance in developing countries elsewhere.

Leased land size cultivated by the household: It was not common practice to lease land to individuals in the research areas. However, there are a few individuals who practiced it on a crop sharing basis, although some leasers will agree on cash terms if the owner of the land needs the money urgently, even if this is not a common practice. Farmers who lease one or more hectares of land are more likely to interact with cooperatives (by 21\%), as they require more inputs to intensify their farming activity. Shifa [90] also found that leased land enhances farmers' communication with cooperatives. However, a one-hectare increase in leased land is likely to reduce households' interaction with water users' associations by 25 percent as farmers leasing land are not supposed to be supported in water management and infrastructure maintenance. Such a negative correlation is rare, although it has been reported in Tajikistan [91].

Oxen ownership: In Africa, oxen (cattle) are mostly kept for plowing [61]. Jaleta et al. (2013) showed that households in Ethiopia with more oxen are more likely to adopt new technologies. Our analysis shows that a one-unit increase in oxen ownership reduces the probability of farmers' interaction with the district office of agriculture by $7 \%$. The FGDs with farmers revealed that better-off farmers (with two or more oxen) were dissatisfied with the quality of the agriculture-related information and the overload of party political ideology. This result is consistent with [92], who found that farmers with more cattle had less contact with the local office of agriculture. With a certain degree of autonomy, wealthy farmers can avoid spending their time interacting with the local agricultural office as they can access farm inputs from private shops and obtain better market information through their networks.

Ownership of a radio: The extension system aims to improve farmers' decision-making skills. Doing so by means of mass media methods requires highly developed infrastructure facilities as well as content preparation, refining and delivery to make the information relevant and useful [93]. Our results show that households with more than one radio have lower levels of interaction with extension agents, district offices of agriculture, 1 to 
5 farmers' groups, development groups and water users' associations (by $2 \%, 10 \%, 8 \%$, $9 \%$ and $13 \%$, respectively). This implies that possession of a radio does not encourage, and indeed actually discourages, farmers from seeking information from agencies. At the same time, for the reasons mentioned above, public extension agencies lack the financial resources to produce radio broadcasts that are relevant to farmers. In addition, we noted that radio coverage in the study areas is generally poor. Our findings are supported by $[23,92]$.

Wealth status of the household: The result shows that poorer households are much more likely $(+15 \%)$ to interact with water users' associations than medium or wealthy households. This implies that poor households articulate their needs and problems better and take more initiatives to meet water users' associations. This is in line with other studies [53] that show that a poor wealth status significantly and positively has an impact on farmers seeking extension advice and suggests that poor farmers are enthusiastic to access agricultural advice from water users' associations in order to escape poverty.

\subsubsection{Groups/Social Capital of the Household Head}

Participation in an Iddir: Negera, et al. [94] described an Iddir as a form of informal insurance in which both men and women participate. Its primary function is to help members cope with shocks (at the death of a family member, following the occurrence of hazards or hard times). The level of interaction of household heads with the district offices of agriculture, cooperatives and water users' associations is strongly influenced by membership to an Iddir, although in different ways.

Farmers' membership to an Iddir increases the probability of interactions with the district office of agriculture (DoA) by $14 \%$. This confirms information from the DoA that evidence of Iddir membership is sometimes needed to obtain support (such as for labor, materials and cash) during hard and risky times. The author [57] also confirmed that membership to an Iddir is associated with improved interactions between farmers and the office of agriculture.

Participation in a Mahiber: Table A4 shows that membership to a Mahiber decreases the probability of interaction with extension agents and the 1 to 5 farmers' groups (by $1 \%$ and $13 \%$, respectively). The FGDs with farmers revealed that the strength of the social network of a Mahiber resolved issues related to shortage of grazing land by regulating access to communal grazing land. Members of a Mahiber were, by default, supposed to join 1 to 5 farmers' groups, but nearly half of them were unhappy with the arrangement. Farmers said that the 1 to 5 farmers' group meetings were tedious and time-consuming and only discussed issues which were not a priority for them, such as political dialogue and the natural resources conservation campaign. A study by Jang, et al. [95] found that members of informal institutions in Ethiopia less often have recourse to extension agencies to resolve agricultural constraints.

Annual participation in agricultural training: Agricultural training is a potentially successful way of disseminating appropriate new technologies to increase farm productivity and reduce rural poverty in sub-Saharan Africa [96]. In many countries, farmers are encouraged to participate in these training sessions to increase technology transfer and improve interaction with extension agencies. However, our results show that household heads who attend more agricultural training sessions per annum are less likely to interact with extension agents, cooperatives and water users' associations. The results indicate that a one-unit increase in annual participation in agricultural training decreases the probability of interaction with extension agents, cooperatives and water users' associations by $0.4 \%$, $3 \%$ and $2 \%$, respectively. This result is unexpected and departs from observations in other contexts $[16,47]$.

In the FGDs, we discussed why agricultural training does not increase interactions with extension agents, cooperatives and water users' associations. The participants replied that this has to do with the nature and types of training provided to farmers. Much training is focused more on politics than on agriculture and addresses model and party member 
farmers rather than ordinary farmers. This finding is supported by [97], who found that most governmental training programs in Ethiopia have political motives and are primarily aimed at fulfilling political objectives rather than improving farmers' incomes. There are no mechanisms in place to evaluate the training sessions. Farmers in the FGDs confirmed that the training sessions did little to help them solve their agricultural problems. Moreover, since they were trained to use inputs that they cannot afford to buy, many farmers are discouraged from attending training programs and focus on local production methods [98].

Annual participation in field days: Attending field days enables farmers to obtain more information and to improve their interaction with extension actors. Most field days in the research area are organized by extension agents. Our results indicate that a one-unit increase in annual participation in a field day decreases the probability of interaction with extension agents, 1 to 5 farmers' groups, development groups and cooperatives by $1 \%, 5 \%$, $4 \%$ and $9 \%$, respectively. Farmers said that there are not enough field days and they are often poorly coordinated and implemented. Farmers were also disappointed in the way that participants for field days are selected. The extension agencies select farmers based on their closeness and nepotism. Farmers also complained that their participation in field days did not help them learn about new topics that could substantially alter their farming system. This finding concurs with a study by [99] in western Kenya, which concluded that in most cases, extension agents' capacity to organize field days is limited.

\subsubsection{Access to Extension Agents}

Physical distance to the nearest extension agent's office: The proximity of farmers to extension agents is important for timely interactions with public extension agencies. We hypothesized that a greater distance will have a negative relationship with farmers' level of interaction. This turned out not to be the case and the correlation was positive, significantly so in the case of interactions with water users' associations. Our result indicates that each increase of one walking minute's distance to the agricultural office increased farmers' interactions with water users' associations to obtain technical information. According to the FGDs with experts, some water users' association offices are located in the same compound as the agricultural extension office, which can also function as an alternative office to access services from water users' associations [100]. Our result is out of line with the literature which normally finds that distance serves as an obstacle for interaction. It is also likely that farmers depend more on other sources, such as 1 to 5 farmers' and farmers' development groups, for their information on irrigation and water use than on agricultural extension agents, especially when they are not accessible to farmers. The authors of [47] found that farmers attending animal health service clinics in Nepal were located nearer to the clinic sites and these farmers had less frequent contact with other extension people.

\section{Conclusions}

This study, which used an ordered probit model, ratifies the importance of the personal and household attributes, farm/plot characteristics and socio-economic and institutional factors in interacting with the range of public extension agencies. These findings demonstrate that poor farmers are more likely to interact with the formal extension system, which is excessively politicized. They cannot afford to evade the surveillance of their political behavior for which the extension system is instrumentalized. Evasion of surveillance is a luxury that only those who are better off can afford, as the above suggests. Even so, this contains an ironic paradox. Although it can be objectively concluded that the packages and technical advice propagated through the extension service are appropriate, firstly, for better-off farmers who have the means to afford the inputs, etc., these results suggest that these better-off farmers will more likely evade the formal extension system, whereas the poorer farmers, to whom the extension packages are not well suited, are, so to speak, forced to engage with the extension system and to undergo the state's political surveillance.

The study suggests that for better farmers' interaction, farmers should obtain the services and support that they need from the relevant authorities, with a focus on capacity 
building. There is also a need to revitalize the training program, enhancing its accessibility, making it demand-driven and reviewing the content of the training program. Formal and informal cooperatives should be empowered to contribute more to the development endeavor, and extension agents should recognize them as contributors to development. These cooperatives also need to provide real and practical extension services, minimize their orientation on distributing consumer goods and improve their trustworthiness in the eyes of both members and non-members. Better-off farmers can lease land and be encouraged to boost production and productivity. The regional bureau of agriculture needs to launch radio programs in collaboration with the regional mass media agencies, which should be attractive and targeted and have an orientation towards problem solving. Water users' associations need to adopt their byelaws and modus operandi so they are customized to local conditions, rather than adopting the regional blueprint for their operational activities. We strongly advise them to consider the local conditions and play a stronger role in disseminating information and knowledge on irrigation-related issues.

Our study only considers farmers' interaction with government agencies. However, the contribution of private and non-governmental actors is indispensable. Therefore, future research should take into account the interaction of farmers with these entities, as well as the interplay between the governmental agencies and non-state actors. Finally, future studies should carefully consider the factors that promote and constrain smallholders' interaction with public extension agencies. There is a need to design contextually appropriate and pro-poor development strategies that enable poor farmers to engage more with extension activities and to encourage them to rely more on their family labor rather than on capitalintensive extension packages.

Author Contributions: Conceptualization, Y.A.G., B.A.W., J.D., M.B. and L.L.; data collection, Y.A.G.; B.A.W. and Z.A; formal analysis, Y.A.G. and B.A.W.; funding acquisition, J.D., B.A.W., A.S.M., Z.A., E.A. and J.N; investigation, Y.A.G.; methodology, Y.A.G., B.A.W. and J.D.; project administration, E.A. and J.N.; resources, Y.A.G., J.D. and A.S.M.; software, Y.A.G. and B.A; supervision, Y.A.G., B.A.W., J.D. and M.B.; validation, Y.A.G. and B.A; writing-original draft, Y.A.G. and B.A.W.; writing-review and editing, Y.A.G., B.A.W., J.D., M.B., L.L., Z.A., A.S.M., E.A. and J.N. All authors have read and agreed to the published version of the manuscript.

Funding: The authors would like to thank the VLIR-UOS project for funding this research through the Bahir Dar University-Institutional University Cooperation (BDU-IUC) program.

Institutional Review Board Statement: Not applicable.

Informed Consent Statement: Informed consent was obtained from all subjects involved in the study.

Data Availability Statement: The data presented in this study are available on request from the corresponding author.

Acknowledgments: We want to thank the Bahir Dar University-Institutional University Cooperation (BDU-IUC) VLIR UOS for providing funding to complete the study. The authors thank the farmers for their willingness to devote time and answer the questions. We would also like to thank the agricultural experts of the districts of Fogera and Mecha. The authors acknowledge the local experts (Yousef Ejigu and Ato Setie Abdi) and data collection participants (Birara Endalew, Mekuanent Lewye, Mekuanent Worku and Bzuayehu Telelaw) for their commitments. Special thanks go to Hanibal Lemma for helping us map the study areas. Finally, the authors thank Nicholas Parrott of TextualHealing.eu for his help in improving the readability and quality of English of this chapter.

Conflicts of Interest: The authors declare no conflict of interest. 


\section{Appendix A}

Table A1. Summary of the definition of variables used in the ordered probit model.

\begin{tabular}{|c|c|c|c|}
\hline Variables & Code & Description & Unit/Rating \\
\hline $\begin{array}{l}\text { Dependent } \\
\text { variable }\end{array}$ & $\begin{array}{l}\text { INF-EAS } \\
\text { INF-DIO } \\
\text { INF-FGS } \\
\text { INF-DGS } \\
\text { INF-COOP } \\
\text { INF-WUAS }\end{array}$ & $\begin{array}{l}\text { Farmer's rating of information and the level of } \\
\text { interaction with } \\
\text { extension agents; } \\
\text { the district office of agriculture; } \\
1 \text { to } 5 \text { farmers' groups; } \\
\text { farmers' development groups; } \\
\text { cooperatives; } \\
\text { water users' associations in the extension system }\end{array}$ & $\begin{array}{l}1=\text { very weak } \\
2=\text { weak } \\
3=\text { strong } \\
4=\text { very strong }\end{array}$ \\
\hline \multirow{26}{*}{$\begin{array}{l}\text { Independent } \\
\text { variables }\end{array}$} & SEX & Sex of the household head & $\begin{array}{l}1=\text { if male-headed } \\
2=\text { if female-headed }\end{array}$ \\
\hline & AGE & Age of the household head & Year \\
\hline & FREXP & Farming experience of the head & Year \\
\hline & ACTIVE & Number of active family member/s & Numbers \\
\hline & DEPENDNT & Number of dependent/s in the family & Numbers \\
\hline & HH-LITERARCY & $\begin{array}{l}\text { If the household head is illiterate or not } \\
\text { (reference category) }\end{array}$ & \\
\hline & HH-READWRITE & If the household head can read and write & Just read and write $=1 ; 0=$ otherwise \\
\hline & HH-PRIMEDU & $\begin{array}{l}\text { If the household head completed } \\
\text { primary education }\end{array}$ & Primary school $=1 ; 0=$ otherwise \\
\hline & HH-SECEDU & $\begin{array}{l}\text { If the household head completed } \\
\text { secondary education }\end{array}$ & Secondary school $=1 ; 0=$ otherwise \\
\hline & NONFARM & Engagement in non-farm activities & $1=$ No $2=$ Yes \\
\hline & ACCESSCREDIT & Access to credit & $1=$ No $2=$ Yes \\
\hline & IDDIR & Membership to Iddir & $1=$ No $2=$ Yes \\
\hline & MAHIBER & Membership to Mahiber & $1=$ No $2=$ Yes \\
\hline & DIST-OFF & Physical distance to extension agent's office & In minutes \\
\hline & AGRTRAINING & Annual participation in agricultural training & Number of times in a year \\
\hline & FIELDDAYS & Annual participation in field day/s & Number of times in a year \\
\hline & MEMB-COOP & Membership to a cooperative & $1=$ No $2=$ Yes \\
\hline & ACCESS-IRRIG & Access to irrigation & $1=$ No $2=$ Yes \\
\hline & OWNEROXEN & Oxen ownership & Number of oxen \\
\hline & LEASELAND & Leased land size cultivated by the household & In hectares \\
\hline & IRRIGLAND & Irrigated land size cultivated by the household & In hectares \\
\hline & RADIO & Ownership of radio & In numbers \\
\hline & MOBILEPHONE & Ownership of mobile phone & In numbers \\
\hline & WEALTH-POOR & If the wealth status of the household is poor & $1=$ poor $; 0=$ otherwise \\
\hline & WEALTH-MID & $\begin{array}{l}\text { If the wealth status of the household is middle } \\
\text { (reference category) }\end{array}$ & \\
\hline & WEALTH-BETTER & If the wealth status of the household is better off & $1=$ better off; $0=$ otherwise \\
\hline
\end{tabular}


Table A2. Spearman's correlation coefficient for continuous variables.

\begin{tabular}{ccccccc}
\hline Variabel & INF-EAS & INF-DO & INF-FGS & INF-DG & INF-COOP & INF-WUAS \\
\hline AGE & $\Gamma=0.05^{* *}$ & $\Gamma=-0.02$ & $\Gamma=0.01$ & $\Gamma=-0.01$ & $\Gamma=0.04$ & $\Gamma=-0.12$ \\
FREXP & $\Gamma=0.04$ & $\Gamma=0.01$ & $\Gamma=0.03$ & $\Gamma=-0.02$ & $\Gamma=-0.04$ & $\Gamma=-0.12$ \\
ACTIVE & $\Gamma=0.15^{*}$ & $\Gamma=-0.03$ & $\Gamma=-0.02$ & $\Gamma=-0.03$ & $\Gamma=-0.05$ & $\Gamma=0.09$ \\
DEPENDNT & $\Gamma=0.16^{* * *}$ & $\Gamma=0.12^{* *}$ & $\Gamma=0.01$ & $\Gamma=0.04$ & $\Gamma=-0.15^{* *}$ & $\Gamma=0.05$ \\
DIST-OFF & $\Gamma=-0.02$ & $\Gamma=-0.04$ & $\Gamma=-0.04$ & $\Gamma=-0.08$ & $\Gamma=0.01$ & $\Gamma=-0.11$ \\
AGRTRAINING & $\Gamma=0.23^{* * *}$ & $\Gamma=0.02$ & $\Gamma=0.07$ & $\Gamma=0.11^{*}$ & $\Gamma=-0.14^{* *}$ & $\Gamma=-0.21^{* *}$ \\
FIELDDAYS & $\Gamma=0.29^{* * *}$ & $\Gamma=0.08$ & $\Gamma=0.22^{* * *}$ & $\Gamma=0.14^{* *}$ & $\Gamma=0.17^{* *}$ & $\Gamma=-0.06$ \\
OWNEROXEN & $\Gamma=0.10^{*}$ & $\Gamma=0.17^{* *}$ & $\Gamma=0.09$ & $\Gamma=0.02$ & $\Gamma=-0.07$ & $\Gamma=-0.02$ \\
IRRIGLAND & $\Gamma=0.15^{*}$ & $\Gamma=0.22^{* * *}$ & $\Gamma=0.08$ & $\Gamma=0.05$ & $\Gamma=0.04$ & $\Gamma=0.19^{* *}$ \\
LEASELAND & $\Gamma=0.09$ & $\Gamma=0.12^{* *}$ & $\Gamma=0.07$ & $\Gamma=0.05$ & $\Gamma=-0.12^{*}$ & $\Gamma=0.26^{* * *}$ \\
RADIO & $\Gamma=0.21^{* * *}$ & $\Gamma=0.16^{* * *}$ & $\Gamma=0.13^{* *}$ & $\Gamma=0.14^{* *}$ & $\Gamma=-0.09$ & $\Gamma=0.14^{*}$ \\
MOBILEPHONE & $\Gamma=0.16^{* * *}$ & $\Gamma=0.11^{*}$ & $\Gamma=-0.01$ & $\Gamma=-0.01$ & $\Gamma=-0.11^{*}$ & $\Gamma=0.12$ \\
\hline
\end{tabular}

$p$-Values * is significant at $p<0.1 ; * *$ is significant at $p<0.05$ and ${ }^{* * *}$ is significant at $p<0.01$.

Table A3. Kruskal-Wallis analysis of variance summary table.

\begin{tabular}{|c|c|c|c|c|c|c|c|c|c|c|c|c|c|}
\hline \multirow{2}{*}{\multicolumn{2}{|c|}{ Variables }} & \multicolumn{2}{|c|}{ INF-EAS } & \multicolumn{2}{|c|}{ INF-DO } & \multicolumn{2}{|c|}{ INF-FGS } & \multicolumn{2}{|c|}{ INF-DG } & \multicolumn{2}{|c|}{ INF-COOP } & \multicolumn{2}{|c|}{ INF-WUAS } \\
\hline & & $\begin{array}{l}\text { Rank } \\
\text { Sum }\end{array}$ & $x^{2}$ & $\begin{array}{l}\text { Rank } \\
\text { Sum }\end{array}$ & $x^{2}$ & $\begin{array}{l}\text { Rank } \\
\text { Sum }\end{array}$ & $x^{2}$ & $\begin{array}{l}\text { Rank } \\
\text { Sum }\end{array}$ & $x^{2}$ & $\begin{array}{l}\text { Rank } \\
\text { Sum }\end{array}$ & $x^{2}$ & $\begin{array}{l}\text { Rank } \\
\text { Sum }\end{array}$ & $x^{2}$ \\
\hline SEX & $\begin{array}{c}\text { Male } \\
\text { Female }\end{array}$ & $\begin{array}{c}43,506 \\
1645\end{array}$ & $2.85 *$ & $\begin{array}{c}40,994 \\
1784\end{array}$ & 1.26 & $\begin{array}{c}43,319 \\
1831\end{array}$ & 0.83 & $\begin{array}{c}43,300 \\
1850\end{array}$ & 0.73 & $\begin{array}{c}23,810 \\
1166\end{array}$ & $2.93 *$ & $\begin{array}{c}9052 \\
265\end{array}$ & 0.02 \\
\hline HH-LITERA & Illiterate & 13,544 & & 13,496 & & 13,983 & & 14,090 & & 6787 & & 2612 & \\
\hline $\begin{array}{c}\text { HH- } \\
\text { READWRITE }\end{array}$ & Literate & 17,608 & $\underset{* *}{9.79}$ & 15,748 & 5.56 & 18,546 & 5.74 & 18,197 & 3.16 & 10,984 & 7.48 & 3931 & 0.81 \\
\hline HH-PRIMEDU & $\begin{array}{c}\text { Primary } \\
\text { school }\end{array}$ & 12,608 & & 12,320 & & 10,692 & & 11,015 & & 6144 & & 2410 & \\
\hline HH-SECEDU & $\begin{array}{l}\text { Secondary } \\
\text { School }\end{array}$ & 1183 & & 1107 & & 1800 & & 1697 & & 1003 & & 303 & \\
\hline NONFARM & $\begin{array}{l}\text { No } \\
\text { Yes }\end{array}$ & $\begin{array}{c}36,110 \\
9041\end{array}$ & 0.82 & $\begin{array}{c}35,110 \\
7668\end{array}$ & 0.80 & $\begin{array}{c}36,647 \\
8503\end{array}$ & 0.02 & $\begin{array}{c}36,152 \\
8999\end{array}$ & 0.57 & $\begin{array}{c}20,496 \\
4480\end{array}$ & 0.00 & $\begin{array}{l}7437 \\
1879\end{array}$ & 0.95 \\
\hline ACCESSCREDIT & $\begin{array}{l}\text { No } \\
\text { Yes }\end{array}$ & $\begin{array}{l}27,477 \\
17,674\end{array}$ & 0.12 & $\begin{array}{l}25,725 \\
17,054\end{array}$ & 0.85 & $\begin{array}{l}27,846 \\
17,305\end{array}$ & 0.05 & $\begin{array}{l}27,337 \\
17,813\end{array}$ & 0.26 & $\begin{array}{c}15,129 \\
9847\end{array}$ & 0.27 & $\begin{array}{l}6466 \\
2850\end{array}$ & 0.63 \\
\hline IDDIR & $\begin{array}{l}\text { No } \\
\text { Yes }\end{array}$ & $\begin{array}{c}5418 \\
39,732\end{array}$ & 1.07 & $\begin{array}{c}6265 \\
36,514\end{array}$ & 2.12 & $\begin{array}{c}5276 \\
39,874\end{array}$ & 1.50 & $\begin{array}{c}5045 \\
40,106\end{array}$ & $\underset{* *}{2.96}$ & $\begin{array}{c}1599 \\
23,378\end{array}$ & $\underset{* * *}{7.01}$ & $\begin{array}{c}800 \\
8516\end{array}$ & 0.49 \\
\hline MAHIBER & $\begin{array}{l}\text { No } \\
\text { Yes }\end{array}$ & $\begin{array}{l}10,919 \\
34,231\end{array}$ & $3.80 *$ & $\begin{array}{l}11,702 \\
31,077\end{array}$ & 1.35 & $\begin{array}{l}10,232 \\
34,918\end{array}$ & $\underset{* * *}{8.06}$ & $\begin{array}{l}11,173 \\
33,978\end{array}$ & 1.90 & $\begin{array}{c}5129 \\
19,848\end{array}$ & 2.69 & $\begin{array}{l}1488 \\
7829\end{array}$ & 1.74 \\
\hline MEMB-COOP & $\begin{array}{l}\text { No } \\
\text { Yes }\end{array}$ & $\begin{array}{l}10,004 \\
35,146\end{array}$ & $\underset{* * *}{7.79}$ & $\begin{array}{l}10,965 \\
31,813\end{array}$ & 0.00 & $\begin{array}{l}11,024 \\
34,127\end{array}$ & 0.81 & $\begin{array}{l}10,937 \\
34,213\end{array}$ & 1.10 & & & $\begin{array}{l}1167 \\
8150\end{array}$ & 0.20 \\
\hline $\begin{array}{l}\text { ACCESS- } \\
\text { IRRIG }\end{array}$ & $\begin{array}{l}\text { No } \\
\text { Yes }\end{array}$ & $\begin{array}{l}11,658 \\
33,493\end{array}$ & 7.19 & $\begin{array}{l}11,590 \\
31,188\end{array}$ & & $\begin{array}{l}13,802 \\
31,348 \\
\end{array}$ & 0.72 & $\begin{array}{l}14,035 \\
31,115\end{array}$ & 1.49 & $\begin{array}{c}7933 \\
17,044\end{array}$ & 1.95 & $\begin{array}{c}825 \\
8491\end{array}$ & 0.26 \\
\hline $\begin{array}{c}\text { WEALTH- } \\
\text { POOR } \\
\text { WEALTH-MID }\end{array}$ & $\begin{array}{l}\text { Poor } \\
\text { Middle- } \\
\text { income }\end{array}$ & $\begin{array}{c}4445 \\
31,306\end{array}$ & $\underset{* *}{8.89}$ & $\begin{array}{c}4789 \\
28,378\end{array}$ & 2.61 & $\begin{array}{c}4469 \\
30,814\end{array}$ & $\underset{* * *}{6.99}$ & $\begin{array}{c}5405 \\
30,655\end{array}$ & 0.75 & $\begin{array}{c}2744 \\
16,530\end{array}$ & 1.03 & $\begin{array}{r}636 \\
6966\end{array}$ & $5.20 *$ \\
\hline $\begin{array}{l}\text { WEALTH- } \\
\text { BETTER }\end{array}$ & Better-off & 9400 & & 9612 & & 9867 & & 9091 & & 5702 & & 1715 & \\
\hline
\end{tabular}


Table A4. Predicted probabilities and marginal effects from the estimated ordered probit model.

\begin{tabular}{|c|c|c|c|c|c|c|c|c|c|c|c|c|}
\hline \multirow{2}{*}{ Variables } & \multicolumn{2}{|c|}{ INF-EAS } & \multicolumn{2}{|c|}{ INF-DO } & \multicolumn{2}{|c|}{ INF-FGS } & \multicolumn{2}{|c|}{ INF-DG } & \multicolumn{2}{|c|}{ INF-COOP } & \multicolumn{2}{|c|}{ INF-WUAS } \\
\hline & Coef./se & $\mathrm{Dy} / \mathrm{dx}$ & Coef./se & $\mathrm{Dy} / \mathrm{dx}$ & Coef./se & Dy/dx & Coef./se & $D y / d x$ & Coef./se & $\mathrm{Dy} / \mathrm{d} x$ & Coef./se & Dy/dx \\
\hline SEX & $\begin{array}{l}-0.07 \\
(0.38)\end{array}$ & 0.00 & $\begin{array}{l}-0.25 \\
(0.45)\end{array}$ & 0.09 & $\begin{array}{c}0.01 \\
(0.31)\end{array}$ & -0.00 & $\begin{array}{l}-0.11 \\
(0.34)\end{array}$ & 0.04 & $\begin{array}{c}0.87 \\
(0.52)\end{array}$ * & -0.35 & $\begin{array}{l}-0.27 \\
(0.59)\end{array}$ & 0.08 \\
\hline AGE & $\begin{array}{l}-0.01 \\
(0.06)\end{array}$ & -0.00 & $\begin{array}{l}-0.00 \\
(0.07)\end{array}$ & 0.00 & $\begin{array}{c}0.03 \\
(0.05)\end{array}$ & -0.01 & $\begin{array}{l}-0.03 \\
(0.05)\end{array}$ & 0.01 & $\begin{array}{c}0.10 \\
(0.06)\end{array}$ * & -0.04 & $\begin{array}{c}-0.072 \\
(0.09)\end{array}$ & 0.02 \\
\hline AGESQ & $\begin{array}{l}-0.00 \\
(0.00)\end{array}$ & $\begin{array}{l}6.1 \times \\
10^{-7}\end{array}$ & $\begin{array}{c}0.00 \\
(0.00)\end{array}$ & 0.00 & $\begin{array}{l}-0.00 \\
(0.00)\end{array}$ & 0.00 & $\begin{array}{c}0.00 \\
(0.00)\end{array}$ & -0.00 & $\begin{array}{l}-0.00 \\
(0.00)\end{array}$ & 0.00 & $\begin{array}{c}0.00 \\
(0.00)\end{array}$ & -0.00 \\
\hline FREXP & $\begin{array}{c}0.01 \\
(0.02) \\
\end{array}$ & -0.00 & $\begin{array}{c}0.03 \\
(0.02)\end{array}$ * & -0.02 & $\begin{array}{c}0.01 \\
(0.02) \\
\end{array}$ & -0.00 & $\begin{array}{c}0.00 \\
(0.02)\end{array}$ & -0.00 & $\begin{array}{c}-0.05 \\
(0.02)\end{array}$ & 0.02 & $\begin{array}{c}0.01 \\
(0.03)\end{array}$ & -0.00 \\
\hline ACTIVE & $\begin{array}{c}0.07 \\
(0.05) \\
\end{array}$ & -0.00 & $\begin{array}{l}-0.05 \\
(0.05)\end{array}$ & 0.02 & $\begin{array}{l}-0.02 \\
(0.04)\end{array}$ & 0.01 & $\begin{array}{l}-0.02 \\
(0.05)\end{array}$ & -0.01 & $\begin{array}{l}-0.02 \\
(0.05)\end{array}$ & 0.01 & $\begin{array}{c}0.1629 \\
(0.08)^{* *}\end{array}$ & -0.05 \\
\hline DEPENDNT & $\begin{array}{c}0.09 \\
(0.06)\end{array}$ & -0.00 & $\begin{array}{c}0.08(0 . \\
07)\end{array}$ & $\begin{array}{l}-0 . \\
03\end{array}$ & $\begin{array}{l}-0.06 \\
(0.05)\end{array}$ & 0.02 & $\begin{array}{l}-0.01 \\
(0.06)\end{array}$ & 0.00 & $\begin{array}{c}-0.14 \\
(0.07)\end{array}$ & 0.06 & $\begin{array}{c}0.09 \\
(0.08)\end{array}$ & -0.03 \\
\hline HH-LITERACY & $\begin{array}{c}0.28 \\
(0.19)\end{array}$ & -0.01 & $\begin{array}{l}-0.01 \\
(0.07)\end{array}$ & -0.01 & $\begin{array}{c}0.29 \\
(0.16)\end{array}$ & 0.09 & $0.22(0.17)$ & 0.07 & $0.26(0.22)$ & -0.10 & $\begin{array}{c}0.08 \\
(0.27) \\
\end{array}$ & -0.02 \\
\hline HH-READWRITE & $\begin{array}{c}0.30 \\
(0.22) \\
\end{array}$ & -0.01 & $\begin{array}{l}-0.12 \\
(0.08) \\
\end{array}$ & -0.12 & $\begin{array}{l}-0.09 \\
(0.20) \\
\end{array}$ & -0.03 & $-0.12(0.20)$ & 0.04 & $\begin{array}{l}-0.20 \\
(0.25) \\
\end{array}$ & 0.08 & $\begin{array}{l}-0.08 \\
(0.31) \\
\end{array}$ & -0.02 \\
\hline HH-PRIMEDU & $\begin{array}{l}-0.32 \\
(0.41)\end{array}$ & 0.02 & $\begin{array}{c}0.10 \\
(0.15)\end{array}$ & 0.10 & $\begin{array}{c}0.52 \\
(0.46)\end{array}$ & -0.13 & $\begin{array}{c}0.06 \\
(0.45)\end{array}$ & -0.02 & $\begin{array}{c}0.44 \\
(0.39)\end{array}$ & -0.17 & $\begin{array}{l}-0.10 \\
(0.50)\end{array}$ & 0.03 \\
\hline NONFARM & $\begin{array}{c}0.31 \\
(0.24)\end{array}$ & -0.01 & $\begin{array}{l}-0.03 \\
(0.07)\end{array}$ & 0.03 & $\begin{array}{c}0.03 \\
(0.18)\end{array}$ & -0.01 & $\begin{array}{c}0.16 \\
(0.19)\end{array}$ & -0.06 & $\begin{array}{l}-0.15 \\
(0.22)\end{array}$ & 0.06 & $\begin{array}{c}0.16 \\
(0.32)\end{array}$ & -0.05 \\
\hline ACCESSCREDIT & $\begin{array}{c}0.03 \\
(0.16)\end{array}$ & -0.00 & $\begin{array}{l}-0.05 \\
(0.05)\end{array}$ & -0.05 & $\begin{array}{c}0.06 \\
(0.14)\end{array}$ & -0.02 & $\begin{array}{c}0.12 \\
(0.14)\end{array}$ & -0.04 & $\begin{array}{c}0.03 \\
(0.18)\end{array}$ & -0.01 & $\begin{array}{l}-0.00 \\
(0.22)\end{array}$ & 0.00 \\
\hline IDDIR & $\begin{array}{l}-0.16 \\
(0.21)\end{array}$ & 0.01 & $\begin{array}{c}0.14 \\
(0.07) *\end{array}$ & 0.14 & $\begin{array}{c}0.00 \\
(0.19)\end{array}$ & -0.00 & $\begin{array}{c}0.12 \\
(0.20)\end{array}$ & -0.04 & $\begin{array}{c}0.73 \\
(0.46)\end{array}$ & -0.29 & $\begin{array}{l}0.58 \\
(0.37)\end{array}$ & -0.17 \\
\hline MAHIBER & $\begin{array}{c}0.25 \\
(0.17)\end{array}$ * & -0.01 & $\begin{array}{l}-0.04 \\
(0.06) \\
\end{array}$ & 0.05 & $\underset{* * *}{0.43(0.15)}$ & -0.13 & $\begin{array}{c}0.17 \\
(0.15) \\
\end{array}$ & -0.06 & $\begin{array}{c}0.27 \\
(0.23) \\
\end{array}$ & -0.11 & $\begin{array}{c}0.44 \\
(0.32) \\
\end{array}$ & -0.13 \\
\hline DIST-OFF & $\begin{array}{l}-0.00 \\
(0.00)\end{array}$ & 0.00 & $\begin{array}{c}0.00 \\
(0.00)\end{array}$ & 0.00 & $\begin{array}{c}0.00 \\
(0.00)\end{array}$ & -0.00 & $\begin{array}{l}-0.00 \\
(0.00)\end{array}$ & 0.00 & $\begin{array}{l}-0.00 \\
(0.00)\end{array}$ & 0.00 & $\begin{array}{c}-0.01 \\
(0.01)^{* *}\end{array}$ & 0.00 \\
\hline AGRTRAINING & $\begin{array}{c}0.09 \\
(0.03)^{* * *}\end{array}$ & -0.00 & $\begin{array}{l}-0.00 \\
(0.00)\end{array}$ & -0.01 & $\begin{array}{c}0.02 \\
(0.02)\end{array}$ & -0.01 & $\begin{array}{c}0.03 \\
(0.02)\end{array}$ & -0.01 & $\begin{array}{c}-0.08 \\
(0.03)^{* * *}\end{array}$ & -0.03 & $\begin{array}{c}-0.070 \\
(0.03) * *\end{array}$ & -0.02 \\
\hline FIELDDAYS & $\begin{array}{c}0.18 \\
(0.08)\end{array}$ & -0.01 & $\begin{array}{l}-0.00 \\
(0.02)\end{array}$ & -0.00 & $\begin{array}{c}0.18 \\
(0.05)^{* * *}\end{array}$ & -0.05 & $\begin{array}{c}0.13 \\
(0.06)^{* *}\end{array}$ & -0.04 & $\begin{array}{c}0.22 \\
(0.07)^{* * *} \\
\end{array}$ & -0.09 & $\begin{array}{l}-0.10 \\
(0.08)\end{array}$ & 0.03 \\
\hline MEMB-COOP & $\begin{array}{c}0.19 \\
(0.17) \\
\end{array}$ & -0.01 & $\begin{array}{l}-0.02 \\
(0.06)\end{array}$ & 0.02 & $\begin{array}{l}-0.10 \\
(0.17) \\
\end{array}$ & 0.03 & $\begin{array}{l}-0.01 \\
(0.16) \\
\end{array}$ & 0.00 & - & - & $\begin{array}{l}-0.35 \\
(0.45) \\
\end{array}$ & 0.10 \\
\hline ACCESS-IRRIG & $\begin{array}{c}0.18 \\
(0.17)\end{array}$ & -0.01 & $\begin{array}{l}-0.05 \\
(0.06)\end{array}$ & 0.05 & $\begin{array}{c}-0.44 \\
(0.16)^{* * *}\end{array}$ & 0.14 & $\begin{array}{c}-0.43 \\
(0.16)^{* * *}\end{array}$ & 0.15 & $\begin{array}{l}-0.27 \\
(0.20) \\
\end{array}$ & 0.11 & $\begin{array}{c}0.23 \\
(0.41)\end{array}$ & -0.07 \\
\hline OWNEROXEN & $\begin{array}{l}-0.05 \\
(0.12)\end{array}$ & 0.00 & $\begin{array}{c}-0.07 \\
(0.04)^{*}\end{array}$ & -0.07 & $0.09(0.09)$ & -0.03 & $0.05(0.10)$ & -0.02 & $\begin{array}{l}-0.06 \\
(0.12)\end{array}$ & 0.02 & $\begin{array}{l}-0.02 \\
(0.17) \\
\end{array}$ & 0.01 \\
\hline IRRIGLAND & $\begin{array}{c}0.50 \\
(0.21)^{* *}\end{array}$ & -0.02 & $\begin{array}{c}-0.17(0 . \\
07)^{* *}\end{array}$ & -0.17 & $\begin{array}{c}0.35 \\
(0.18)^{* *}\end{array}$ & -0.11 & $\begin{array}{c}0.53 \\
(0.19)^{* * *} \\
\end{array}$ & -0.18 & $\begin{array}{l}-0.19 \\
(0.24)\end{array}$ & 0.08 & $\begin{array}{c}0.70 \\
(0.28)^{* *}\end{array}$ & -0.20 \\
\hline LEASELAND & $\begin{array}{c}0.03 \\
(0.25) \\
\end{array}$ & -0.00 & $\begin{array}{l}-0.05 \\
(0.08) \\
\end{array}$ & -0.05 & $\begin{array}{c}0.15 \\
(0.22) \\
\end{array}$ & $\begin{array}{l}-0 . \\
05\end{array}$ & $\begin{array}{c}0.03 \\
(0.22) \\
\end{array}$ & 0.01 & $\begin{array}{c}-0.41 \\
(0.32)\end{array}$ & 0.16 & $\begin{array}{c}0.86 \\
(0.39)^{* *}\end{array}$ & -0.25 \\
\hline RADIO & $\begin{array}{c}0.32 \\
(0.15)^{* *}\end{array}$ & -0.02 & $\begin{array}{c}0.10 \\
(0.05)^{* *}\end{array}$ & -0.10 & $\begin{array}{c}0.25 \\
(0.14)\end{array}$ * & -0.08 & $\begin{array}{c}0.27 \\
(0.15)\end{array}$ * & -0.09 & $\begin{array}{l}-0.08 \\
(0.19)\end{array}$ & 0.03 & $\begin{array}{c}0.46 \\
(0.27)^{* *}\end{array}$ & -0.13 \\
\hline MOBILEPHONE & $\begin{array}{c}0.07 \\
(0.09) \\
\end{array}$ & -0.00 & $\begin{array}{l}-0.01 \\
(0.03)\end{array}$ & -0.01 & $\begin{array}{l}-0.10 \\
(0.08) \\
\end{array}$ & 0.03 & $\begin{array}{l}-0.09 \\
(0.08) \\
\end{array}$ & 0.03 & $\begin{array}{l}-0.07 \\
(0.10)\end{array}$ & 0.03 & $\begin{array}{c}0.10 \\
(0.11)\end{array}$ & -0.03 \\
\hline WEALTH-POOR & $\begin{array}{l}-0.23 \\
(0.24)\end{array}$ & 0.01 & $\begin{array}{l}-0.00 \\
(0.09)\end{array}$ & -0.00 & $\begin{array}{l}-0.44 \\
(0.23)\end{array}$ & -0.15 & $-0.10(0.21)$ & 0.03 & $\begin{array}{c}0.22 \\
(0.31)\end{array}$ & -0.09 & $\begin{array}{c}-0.65 \\
(0.56)^{* * *}\end{array}$ & 0.14 \\
\hline WEALTH-BETTER & $\begin{array}{l}-0.03 \\
(0.21)\end{array}$ & 0.02 & $\begin{array}{c}0.01 \\
(0.07) \\
\end{array}$ & 0.01 & $\begin{array}{l}-0.05 \\
(0.18) \\
\end{array}$ & 0.02 & $\begin{array}{c}-0.23(0 \\
18)\end{array}$ & 0.08 & $\begin{array}{c}0.23 \\
(0.23) \\
\end{array}$ & 0.09 & $\begin{array}{l}-0.88 \\
(0.31) \\
\end{array}$ & 0.29 \\
\hline /cut1 & 0.0799 & & -0.0975 & & 0.0844 & & -0.9864 & & 3.4130 & & -0.6281 & \\
\hline /cut2 & 0.7893 & & 1.1158 & & 1.1145 & & 0.1202 & & 5.3507 & & 0.6158 & \\
\hline /cut3 & 1.7848 & & 1.8258 & & 2.0669 & & 1.0349 & & 5.7003 & & 1.3479 & \\
\hline Log pseudolikel. & -260.250 & & -192.737 & & -373.517 & & -363.225 & & -165.341 & & -157.241 & \\
\hline Wald chi2 & 68.68 & & 43.46 & & 52.80 & & 35.25 & & 57.89 & & 84.61 & \\
\hline Pseudo R2 & 0.1272 & & 0.0893 & & 0.0637 & & 0.0468 & & 0.1364 & & 0.1369 & \\
\hline Number of obs. & 300 & & 292 & & 300 & & 300 & & 223 & & 136 & \\
\hline
\end{tabular}

$* * * * * *$ stand for values statistically significant at $0.01,0.05$ and 0.1 levels, respectively, and $b=\mathrm{dy} / \mathrm{dx}$ is for discrete change of dummy variable from 0 to 1 ; robust standard errors are in parenthesis. 


\section{References}

1. Drafor, I. Access to information for farm-level decision-making. J. Agric. Food Inf. 2016, 17, 230-245. [CrossRef]

2. Biratu, G.K. Agricultural Extension and Its Impact on Food Crop Diversity and the Livelihood of Farmers in Guduru, Eastern Wollega, Master of Science, Universitetet for Miljø- og Biovitenskap; Norwegian University of Life Sciences (UMB): Ås, Norway, 2008.

3. Adekunle, A.; Fatunbi, A. A new theory of change in african agriculture. Middle-East J. Sci. Res. 2014, 21, 1083-1096.

4. Norton, G.W.; Alwang, J. Changes in agricultural extension and implications for farmer adoption of new practices. Appl. Econ. Perspect. Policy 2020, 42, 8-20. [CrossRef]

5. Taylor, M.; Bhasme, S. Model farmers, extension networks and the politics of agricultural knowledge transfer. J. Rural Stud. 2018, 64, 1-10. [CrossRef]

6. Barrett, C.B.; Mude, A.G.; Omiti, J. Decentralization and the Social Economics of Development; CABI, Wallingford Town Hall: Wallingford, CT, USA, 2007.

7. Amankwah, K.; Shtaltovna, A.; Kelboro, G.; Hornidge, A.-K. A Critical Review of the Follow-the-Innovation Approach: Stakeholder Collaboration and Agricultural Innovation Development; ZEF Working Paper Series; Center for Development Research: Bonn, Germany, 2015.

8. Charles, S.J.; Mattee, A.Z.; Msuya-Bengesi, C.P. Interactions among actors in improved rice varieties innovation system in the eastern zone of tanzania. Afr. J. Sci. Technol. Innov. Dev. 2020, 1-15. [CrossRef]

9. Ali, J. Factors affecting the adoption of information and communication technologies (icts) for farming decisions. J. Agric. Food Inf. 2012, 13, 78-96. [CrossRef]

10. Kumba, F.F. Farmer participation in agricultural research and extension service in namibia. J. Int. Agric. Ext. Educ. 2003, 10, 47-55. [CrossRef]

11. Turner, J.A.; Rijswijk, K.; Williams, T.; Barnard, T.; Klerkx, L. Challenges to effective interaction in the new zealand agricultural research and extension system: An innovation systems analysis. Ext. Farming Syst. J. 2013, 9, 89-98.

12. Jack, C.; Adenuga, A.H.; Ashfield, A.; Wallace, M. Investigating the drivers of farmers' engagement in a participatory extension programme: The case of northern ireland business development groups. Sustainability 2020, 12, 4510. [CrossRef]

13. Hoang, L.A.; Castella, J.-C.; Novosad, P. Social networks and information access: Implications for agricultural extension in a rice farming community in northern vietnam. Agric. Hum. Values 2006, 23, 513-527. [CrossRef]

14. Ragasa, C.; Ulimwengu, J.; Randriamamonjy, J.; Badibanga, T. Factors affecting performance of agricultural extension: Evidence from democratic republic of congo. J. Agric. Educ. Ext. 2016, 22, 113-143. [CrossRef]

15. Mikwamba, K.; Dessein, J.; Kambewa, D. Fighting banana bunchy top disease in southern malawi. The interface of knowledge systems and dynamics in a development arena. J. Agric. Educ. Ext. 2020, 26, 163-182. [CrossRef]

16. Agidew, A.-M.A.; Singh, K. Factors affecting farmers' participation in watershed management programs in the northeastern highlands of ethiopia: A case study in the teleyayen sub-watershed. Ecol. Process. 2018, 7, 15. [CrossRef]

17. Teklu, T.; Lemi, A. Factors affecting entry and intensity in informal rental land markets in southern ethiopian highlands. Agric. Econ. 2004, 30, 117-128. [CrossRef]

18. Bewket, W. Soil and water conservation intervention with conventional technologies in northwestern highlands of ethiopia: Acceptance and adoption by farmers. Land Use Policy 2007, 24, 404-416. [CrossRef]

19. Woldenhanna, T.; Oskam, A. Income diversification and entry barriers: Evidence from the tigray region of northern ethiopia. Food Policy 2001, 26, 351-365. [CrossRef]

20. Abebe, A.; Mammo Cherinet, Y. Factors affecting the use of information and communication technologies for cereal marketing in ethiopia. J. Agric. Food Inf. 2019, 20, 59-70. [CrossRef]

21. Ariga, J.; Mabaya, E.; Waithaka, M.; Wanzala-Mlobela, M. Can improved agricultural technologies spur a green revolution in africa? A multicountry analysis of seed and fertilizer delivery systems. Agric. Econ. 2019, 50, 63-74. [CrossRef]

22. Belay, K. Constraints to agricultural extension work in ethiopia: The insiders' view. S. Afr. J. Agric. Ext. 2002, 31, 63-79.

23. Van Rijn, F.; Nkonya, E.; Adekunle, A. The impact of agricultural extension services on social capital: An application to the sub-saharan african challenge program in lake kivu region. Agric. Hum. Values 2015, 32, 597-615. [CrossRef]

24. Berhane, G.; Ragasa, C.; Abate, G.T.; Assefa, T.W. The State of Agricultural Extension Services in Ethiopia and Their Contribution to Agricultural Productivity; Intl Food Policy Res Inst (IFPRI): Washington, DC, USA, 2018.

25. Abegaz, D.M.; Wims, P. Extension agents' awareness of climate change in ethiopia. J. Agric. Educ. Ext. 2015, 21, 479-495. [CrossRef]

26. Berhanu, A. The Ethiopian Extension and the Farmer: A View from the Farm. In Proceedings of the 16th International Conference of Ethiopian Studies; Kluwer Academic: Trondheim, Norway, 2009.

27. MoFED. Growth and Transformation Plan (2010/11-2014/15); Ministry of Finance and Economic Development (MoFED) Addis Ababa: Addis Ababa, Ethiopia, 2010.

28. Leta, G.; Kelboro, G.; Stellmacher, T.; Hornidge, A.-K. The Agricultural Extension System in Ethiopia: Operational Setup, Challenges and Opportunities; ZEF Center for Development Research University of Bonn: Bonn, Germany, 2017.

29. Tarekegn, K.; Haji, J.; Tegegne, B. Determinants of honey producer market outlet choice in chena district, southern ethiopia: A multivariate probit regression analysis. Agric. Food Econ. 2017, 5, 20. [CrossRef]

30. Yami, M. Sustaining participation in irrigation systems of ethiopia: What have we learned about water user associations? Water Policy 2013, 15, 961-984. [CrossRef] 
31. Snyder, K.A.; Ludi, E.; Cullen, B.; Tucker, J.; Zeleke, A.B.; Duncan, A. Participation and performance: Decentralised planning and implementation in ethiopia. Public Adm. Dev. 2014, 34, 83-95. [CrossRef]

32. FOARD. Planning document for agriculture sectors; District office of Agriculture: Woreta, Ethiopia, 2017.

33. North Mecha District Office of Agriculture. Planning Document for Agriculture Sectors; Amharic Language: Amhara, Merawi, 2017.

34. Kothari, C.R. Research methodology: Methods and Techniques; New Age International: New Delhi, India, 2004.

35. Wooldridge, J.M. Econometric Analysis of Cross Section and Panel Data; MIT Press: Cambridge, MA, USA, $2002 ;$ Volume 108.

36. Greene, W.H. Econometric Analysis, 5th ed.; International edition; Prentice Hall: Upper Saddle River, NJ, USA, $2003 ;$ pp. $201-215$.

37. Occelli, M.; Mantino, A.; Ragaglini, G.; Dell'Acqua, M.; Fadda, C.; Pè, M.E.; Nuvolari, A. Traditional knowledge affects soil management ability of smallholder farmers in marginal areas. Agron. Sustain. Dev. 2021, 41, 1-15. [CrossRef]

38. Wordofa, M.G.; Okoyo, E.N.; Erkalo, E. Factors influencing adoption of improved structural soil and water conservation measures in eastern ethiopia. Environ. Syst. Res. 2020, 9, 1-11. [CrossRef]

39. Midingoyi, S.K.G.; Kassie, M.; Muriithi, B.; Diiro, G.; Ekesi, S. Do farmers and the environment benefit from adopting integrated pest management practices? Evidence from kenya. J. Agric. Econ. 2019, 70, 452-470. [CrossRef]

40. Biru, W.D.; Zeller, M.; Loos, T.K. The impact of agricultural technologies on poverty and vulnerability of smallholders in ethiopia: A panel data analysis. Soc. Indic. Res. 2020, 147, 517-544. [CrossRef]

41. Usman, Z.O.; Olagunju, K.O.; Ogunpaimo, O.R. Determinants of adoption of multiple sustainable agricultural practices among smallholder farmers in nigeria. Int. Soil Water Conserv. Res. 2020. [CrossRef]

42. Negatu, W.; Parikh, A. The impact of perception and other factors on the adoption of agricultural technology in the moret and jiru woreda (district) of ethiopia. Agric. Econ. 1999, 21, 205-216. [CrossRef]

43. Borooah, V.K. Logit and Probit: Ordered and Multinomial Models; Saga University: Thousand Oaks, CA, USA, 2002.

44. Gill, J. Interpreting Interactions and Interaction Hierarchies in Generalized Linear Models: Issues and Applications; Annual Meeting of the American Political Science Association: San Francisco, CA, USA, 2001.

45. Mudege, N.N.; Mdege, N.; Abidin, P.E.; Bhatasara, S. The role of gender norms in access to agricultural training in chikwawa and phalombe, malawi. Gend. Place Cult. 2017, 24, 1689-1710. [CrossRef]

46. David, I.I.; Abbyssinia, M. Factors affecting smallholder farmers' perception regarding their use of soil conservation practices: Evidence from farming at qamata irrigation scheme, south africa. J. Hum. Ecol. 2017, 59, 82-91. [CrossRef]

47. Adhikari, R.; Regmi, P.; Thapa, R.; GC, Y.D.; Boa, E. Determinants of farmers' participation in plant health clinics in nepal. J. Agric. Sci 2016, 14, 290-299.

48. Amare, A.; Simane, B. Determinants of smallholder farmers' decision to adopt adaptation options to climate change and variability in the muger sub basin of the upper blue nile basin of ethiopia. Agric. Food Secur. 2017, 6, 64. [CrossRef]

49. Chandio, A.A.; Yuansheng, J. Determinants of adoption of improved rice varieties in northern sindh, pakistan. Rice Sci. 2018, 25, 103-110. [CrossRef]

50. Gebrehiwot, K.G. The impact of agricultural extension on farmers' technical efficiencies in ethiopia: A stochastic production frontier approach. S. Afr. J. Econ. Manag. Sci. 2017, 20,1-8. [CrossRef]

51. Suvedi, M.; Ghimire, R.; Kaplowitz, M. Farmers' participation in extension programs and technology adoption in rural nepal: A logistic regression analysis. J. Agric. Educ. Ext. 2017, 23, 351-371. [CrossRef]

52. Beyene, A.D. Determinants of off-farm participation decision of farm households in ethiopia. Agrekon 2008, 47, 140-161. [CrossRef]

53. Mwololo, H.; Nzuma, J.; Ritho, C. Do farmers' socio-economic characteristics influence their preference for agricultural extension methods? Dev. Pract. 2019, 29, 844-853. [CrossRef]

54. Demeke, A.B.; Keil, A.; Zeller, M. Using panel data to estimate the effect of rainfall shocks on smallholders food security and vulnerability in rural ethiopia. Clim. Chang. 2011, 108, 185-206. [CrossRef]

55. Sithole, N.L.; Lagat, J.K.; Masuku, M.B. Factors influencing farmers participation in smallholder irrigation schemes: The case of ntfonjeni rural development area. J. Econ. Sustain. Dev. 2014, 5, 157-167.

56. Odoh, N.E.; Nwibo, S.U.; Eze, A.V.; Igberi, C.O. Farm and non-farm income diversification activities among rural households in southeast, nigeria. J. Agric. Ext. 2019, 23, 113-121. [CrossRef]

57. Aredo, D. The iddir: An informal insurance arrangement in ethiopia. Sav. Dev. 2010, 34, 53-72.

58. Endalew, B.; Wondimagegnhu, B.A. Determinants of households' willingness to pay for the conservation of church forests in northwestern ethiopia: A contingent valuation study. Cogent Environ. Sci. 2019, 5, 1570659. [CrossRef]

59. Deneke, T.T.; Gulti, D. Agricultural research and extension linkages in the amhara region, ethiopia. In Technological and Institutional Innovations for Marginalized Smallholders in Agricultural Development; Springer: Cham, Switzerland, 2016; pp. 113-124.

60. Egziabher, K.G.; Mathijs, E.; Deckers, J.; Gebrehiwot, K.; Bauer, H.; Maertens, M. The Economic Impact of a New Rural Extension Approach in Northern Ethiopia; Working Paper; University of Leuven, Geo-Institute, Department of Earth and Environmental Sciences, Division of Bioeconomics: Leuven, Belgium, 2013; Volume 2.

61. Wilson, R.T. The environmental ecology of oxen used for draught power. Agric. Ecosyst. Environ. 2003, 97, 21-37. [CrossRef]

62. Debela, B.L. Factors affecting differences in livestock asset ownership between male-and female-headed households in northern ethiopia. Eur. J. Dev. Res. 2017, 29, 328-347. [CrossRef]

63. Miheretu, B.A.; Yimer, A.A. Determinants of farmers' adoption of land management practices in gelana sub-watershed of northern highlands of ethiopia. Ecol. Process. 2017, 6, 19. [CrossRef] 
64. Chamberlin, J.; Jayne, T. Does farm structure affect rural household incomes? Evidence from tanzania. Food Policy 2020, 90, 101805. [CrossRef]

65. Aker, J.C. Dial "a" for agriculture: A review of information and communication technologies for agricultural extension in developing countries. Agric. Econ. 2011, 42, 631-647. [CrossRef]

66. Mammo, Y. Icts in Linking Farmers to Markets: Innovative Mobile Applications and Lessons Learned from the Past and the Future; CTA: Rome, Italy, 2015.

67. Hailemichael, S.; Haug, R. The use and abuse of the 'model farmer'approach in agricultural extension in ethiopia. J. Agric. Educ. Ext. 2020, 26, 465-484. [CrossRef]

68. Adimassu, Z.; Langan, S.; Johnston, R. Understanding determinants of farmers' investments in sustainable land management practices in ethiopia: Review and synthesis. Environ. Dev. Sustain. 2016, 18, 1005-1023. [CrossRef]

69. Babulo, A.A. Assessment of the financial and operational performance of micro finance institutions. Sustain. Hum. 2020, 16, 925-943.

70. Amha, G.G. Determinants of customer satisfaction and customer loyalty in amhara credit and saving institute (acsi): The case of waghimera zone sekota town. Int. J. Mark. Hum. Resour. Res. 2020, 1, 34-51.

71. Ramberg, L. Farmer Knowledge Sharing and Social Networks in Agricultural Extension; Sveriges Lantbruksuniversitet: Uppsala, Sweden, 2020; pp. 20-25.

72. Sisay, D.T.; Verhees, F.J.; Van Trijp, H.C. Seed producer cooperatives in the ethiopian seed sector and their role in seed supply improvement: A review. J. Crop Improv. 2017, 31, 323-355. [CrossRef]

73. Zewdie, M.C.; Van Passel, S.; Moretti, M.; Annys, S.; Tenessa, D.B.; Ayele, Z.A.; Tsegaye, E.A.; Cools, J.; Minale, A.S.; Nyssen, J. Pathways how irrigation water affects crop revenue of smallholder farmers in northwest ethiopia: A mixed approach. Agric. Water Manag. 2020, 233, 106101. [CrossRef]

74. Bello-Bravo, J.; Lutomia, A.N.; Abbott, E.; Mazur, R.; Mocumbe, S.; Pittendrigh, B.R. Making agricultural learning accessible: Examining gender in the use of animations via mobile phones. In Empowering Learners with Mobile Open-Access Learning Initiatives; IGI Global: Hershey, PA, USA, 2017.

75. Woldu, T.; Tadesse, F. Women's participation in agricultural cooperatives in ethiopia. In Agriculture in an Interconnected World; International Association of Agricultural Economists: Milan, Italy, 2015.

76. Abebaw, D.; Haile, M.G. The impact of cooperatives on agricultural technology adoption: Empirical evidence from ethiopia. Food Policy 2013, 38, 82-91. [CrossRef]

77. Jensen-Auvermann, T.; Adams, I.; Doluschitz, R. Trust—factors that have an impact on the interrelations between members and employees in rural cooperatives. J. Co-Oper. Organ. Manag. 2018, 6, 100-110. [CrossRef]

78. Gebru, B.M.; Wang, S.W.; Kim, S.J.; Lee, W.-K. Socio-ecological niche and factors affecting agroforestry practice adoption in different agroecologies of southern tigray, ethiopia. Sustainability 2019, 11,3729. [CrossRef]

79. Balasubramanya, S. Effects of training duration and the role of gender on farm participation in water user associations in southern tajikistan: Implications for irrigation management. Agric. Water Manag. 2019, 216, 1-11. [CrossRef]

80. MacDonald, K. The user and the association: Neglecting household irrigation as neglecting household well-being in the creation of water users' associations in the republic of tajikistan. Water 2019, 11, 505. [CrossRef]

81. Myeni, L.; Moeletsi, M.; Thavhana, M.; Randela, M.; Mokoena, L. Barriers affecting sustainable agricultural productivity of smallholder farmers in the eastern free state of south africa. Sustainability 2019, 11, 3003. [CrossRef]

82. Ahmed, M.H.; Mesfin, H.M. The impact of agricultural cooperatives membership on the wellbeing of smallholder farmers: Empirical evidence from eastern ethiopia. Agric. Food Econ. 2017, 5, 1-20. [CrossRef]

83. Priscilla, L.; Chauhan, A.; Nagrale, B.G. Determinants of participation of dairy farmers in dairy cooperative societies in manipur. Indian J. Econ. Dev. 2016, 12, 377-379. [CrossRef]

84. Pratiwi, A.; Suzuki, A. Effects of farmers' social networks on knowledge acquisition: Lessons from agricultural training in rural indonesia. J. Econ. Struct. 2017, 6, 8. [CrossRef]

85. Huluka, A.T.; Wondimagegnhu, B.A. Determinants of household dietary diversity in the yayo biosphere reserve of ethiopia: An empirical analysis using sustainable livelihood framework. Cogent Food Agric. 2019, 5, 1690829. [CrossRef]

86. Gashaw, B.A.; Kibret, S.M. Factors influencing farmers' membership preferences in agricultural cooperatives in ethiopia. Am. J. Rural Dev. 2018, 6, 94-103.

87. Tesfaye, A.; Bogale, A.; Namara, R.E.; Bacha, D. The impact of small-scale irrigation on household food security: The case of filtino and godino irrigation schemes in ethiopia. Irrig. Drain. Syst. 2008, 22, 145-158. [CrossRef]

88. Dörre, A. Collaborative action and social organization in remote rural regions: Autonomous irrigation arrangements in the pamirs of tajikistan. Water 2020, 12, 2905. [CrossRef]

89. Playán Jubillar, E.; Sagardoy, J.A.; Castillo, R. Irrigation governance in developing countries: Current problems and solutions. Water 2018, 10, 1118. [CrossRef]

90. Shifa, M. Determinants of land and labour market participation decisions in rural ethiopia. J. Afr. Dev. 2016, 18, 73-90.

91. Balasubramanya, S.; Price, J.P.; Horbulyk, T.M. Impacts assessments without true baselines: Assessing the relative effects of training on the performance of water user associations in southern tajikistan. Water Econ. Policy 2018, 4, 1850007. [CrossRef]

92. Teklewold, H.; Kassie, M.; Shiferaw, B. Adoption of multiple sustainable agricultural practices in rural ethiopia. J. Agric. Econ. 2013, 64, 597-623. [CrossRef] 
93. Wijerathna, M.; Wanigasundera, W. "Communication" in the Context of Agricultural Extension: Past, Present and Way Forward in Achieving Sustainable Food Systems in Sri Lanka. Available online: https:/ / doi.org/10.1007/978-981-15-3673-1_18 (accessed on 25 January 2021).

94. Negera, C.U.; Bekele, A.E.; Wondimagegnehu, B.A. The role of informal local institutions in food security of rural households in southwest ethiopia. Int. J. Community Soc. Dev. 2019, 1, 124-144. [CrossRef]

95. Jang, D.; Atkinson, J.; Park, K. Can informal traditional institutions mediate risk preferences among smallholder farmers?-evidence from rural ethiopia. J. Agric. Ext. Community Dev. 2016, 23, 169-180.

96. Nakano, Y.; Tsusaka, T.W.; Aida, T.; Pede, V.O. Is farmer-to-farmer extension effective? The impact of training on technology adoption and rice farming productivity in tanzania. World Dev. 2018, 105, 336-351. [CrossRef]

97. Cochrane, L. Worldviews apart: Agricultural extension and ethiopian smallholder farmers. J. Rural Soc. Sci. $2017,32,7$.

98. Leta Dufera, G. The Ethiopian Agricultural Extension System and Its Role as a Development Actor; Universität Bonn: Bonn, Germany, 2018. Available online: https://bonndoc.ulb.uni-bonn.de/xmlui/bitstream/handle $/ 20.500 .11811 / 7359 / 5176$.pdf?sequence= 1\&isAllowed =y (accessed on 25 January 2021).

99. Amudavi, D.M.; Khan, Z.R.; Wanyama, J.M.; Midega, C.A.; Pittchar, J.; Hassanali, A.; Pickett, J.A. Evaluation of farmers' field days as a dissemination tool for push-pull technology in western kenya. Crop Prot. 2009, 28, 225-235. [CrossRef]

100. Ricks, J.I. Building participatory organizations for common pool resource management: Water user group promotion in indonesia. World Dev. 2016, 77, 34-47. [CrossRef] 